\title{
Role of biomechanics in the understanding of normal, injured, and healing ligaments and tendons Ho-Joong Jung ${ }^{1,2}$, Matthew B Fisher ${ }^{1}$ and Savio L-Y Woo*1
}

Address: ${ }^{1}$ Musculoskeletal Research Center, Department of Bioengineering, Swanson School of Engineering, University of Pittsburgh, Pittsburgh, USA and ${ }^{2}$ Department of Orthopaedic Surgery, College of Medicine, Chung-Ang University, Seoul, Korea

Email: Ho-Joong Jung - sunu@cau.ac.kr; Matthew B Fisher - mbf7@pitt.edu; Savio L-Y Woo* - ddecenzo@pitt.edu

* Corresponding author

Published: 20 May 2009

Sports Medicine, Arthroscopy, Rehabilitation, Therapy \& Technology 2009, I:9 doi:10.1 I86/1758-2555-I-9

This article is available from: http://www.smarttjournal.com/content/I/I/9

(c) 2009 Jung et al; licensee BioMed Central Ltd.

This is an Open Access article distributed under the terms of the Creative Commons Attribution License (http://creativecommons.org/licenses/by/2.0), which permits unrestricted use, distribution, and reproduction in any medium, provided the original work is properly cited.
Received: 6 April 2009

Accepted: 20 May 2009

\begin{abstract}
Ligaments and tendons are soft connective tissues which serve essential roles for biomechanical function of the musculoskeletal system by stabilizing and guiding the motion of diarthrodial joints. Nevertheless, these tissues are frequently injured due to repetition and overuse as well as quick cutting motions that involve acceleration and deceleration. These injuries often upset this balance between mobility and stability of the joint which causes damage to other soft tissues manifested as pain and other morbidity, such as osteoarthritis.

The healing of ligament and tendon injuries varies from tissue to tissue. Tendinopathies are ubiquitous and can take up to 12 months for the pain to subside before one could return to normal activity. A ruptured medial collateral ligament (MCL) can generally heal spontaneously; however, its remodeling process takes years and its biomechanical properties remain inferior when compared to the normal MCL. It is also known that a midsubstance anterior cruciate ligament $(\mathrm{ACL})$ tear has limited healing capability, and reconstruction by soft tissue grafts has been regularly performed to regain knee function. However, long term follow-up studies have revealed that 20 $25 \%$ of patients experience unsatisfactory results. Thus, a better understanding of the function of ligaments and tendons, together with knowledge on their healing potential, may help investigators to develop novel strategies to accelerate and improve the healing process of ligaments and tendons.

With thousands of new papers published in the last ten years that involve biomechanics of ligaments and tendons, there is an increasing appreciation of this subject area. Such attention has positively impacted clinical practice. On the other hand, biomechanical data are complex in nature, and there is a danger of misinterpreting them. Thus, in these review, we will provide the readers with a brief overview of ligaments and tendons and refer them to appropriate methodologies used to obtain their biomechanical properties. Specifically, we hope the reader will pay attention to how the properties of these tissues can be altered due to various experimental and biologic factors. Following this background material, we will present how biomechanics can be applied to gain an understanding of the mechanisms as well as clinical management of various ligament and tendon ailments. To conclude, new technology, including imaging and robotics as well as functional tissue engineering, that could form novel treatment strategies to enhance healing of ligament and tendon are presented.
\end{abstract}




\section{Introduction}

Ligaments and tendons are soft connective tissues which transmit forces from bone to bone and muscle to bone, respectively. These unique tissues serve essential roles for biomechanical function of the musculoskeletal system by stabilizing and guiding the motion of diarthrodial joints. To accomplish this, ligaments and tendons have a hierarchy of highly aligned collagen composed of fibrils, fascicles, fibers, and the tissue itself, to form one of the strongest tissues in the body. Nevertheless, these tissues are frequently injured due to repetition and overuse, eccentric activities, and quick cutting motions that involve acceleration and deceleration. These injuries often upset this balance between mobility and stability of the joint which results in abnormal loading that could damage other soft tissues in and around the joint manifested as pain and other morbidity, such as osteoarthritis [1-6].

The numbers on incidence of ligament and tendon injuries are huge. For example, it is estimated that tendinopathy accounts for $30 \%$ to $50 \%$ of all injuries related to sports, plus over $48 \%$ in occupational maladies [6-8]. Achilles tendinopathy accounts for $7-11 \%$ of all running injuries [9-11]. Similarly, the incidence of knee ligament ruptures, primarily involving the anterior cruciate ligament (ACL) and the medial collateral ligament (MCL), is estimated to be 2 per 1,000 people per year in the general population $[12,13]$. In the shoulder, injuries to the ligaments and capsule results in approximately 34,000 dislocations occur per year in the young adult population $[14,15]$, and rotator cuff tears in more than $30 \%$ of people over 60 years of age $[16,17]$.

The healing of ligament and tendon injuries, if it takes place, is usually slow. Tendinopathies, including tendinosis, tendonitis, and paratenonitis, are ubiquitous, occurring in the Achilles, patellar, quadriceps, hamstrings, and rotator cuff tendons as well as in the elbow, wrist and hand joints. These detrimental injuries can take up to 12 months for the pain to subside before one could return to physical and sports activity [6]. Further, although a ruptured MCL can generally heal spontaneously and sufficiently well such that nonsurgical management has become the treatment of choice [18-25], its remodeling process takes years, and its mechanical properties remain inferior to those for the normal MCL [18,23,24,26-30]. It is also known that a midsubstance ACL tear has limited healing capability [20,31-33] and reconstruction by replacement grafts has been regularly performed in order to regain knee function [34-37].

Well over 100,000 of these procedures are done per year in the U.S. alone [13]. However, long term follow-up studies have revealed that $20-25 \%$ of patients experience unsatisfactory results at 7 to 10 years following ACL reconstruction [1-5]. Thus, it is clear that a better understanding of the function of ligaments and tendons, together with knowledge on their biology and healing potential, is needed for investigators to develop novel strategies to accelerate and improve the process of healing of ligaments and tendons. Well over 4000 new papers have been published in the last ten years that involve biomechanics of ligaments and tendons. As a result, orthopaedic surgeons and other health related professionals have an increasing appreciation of the importance of this subject area and have use for biomechanical findings to help their clinical practice. On the other hand, biomechanical data are complex in nature, and there is a danger of misinterpreting them. Thus, we wish to provide the readers with a brief overview of ligaments and tendons and point them to appropriate methodologies used to obtain the biomechanical properties of these soft tissues [38-43]. More importantly, how the properties of these tissues can be altered due to various experimental and biologic factors will be discussed [44-52]. Following this background material, we will present how biomechanics can be applied to gain an understanding of the mechanisms and management of various ligament and tendon injuries. Examples given will include tendinopathy, as well as MCL and ACL tears. To conclude, new technology, including imaging and robotics as well as functional tissue engineering, that could form novel treatment strategies to enhance ligament and tendon healing will be presented [53-61].

\section{Basic biomechanics on ligaments and tendons Definition of biomechanical properties}

Because the primary function of ligaments and tendons is to transmit tensile forces, experimental studies of the biomechanical properties of these tissues are generally performed in uniaxial tension. Testing isolated ligament and tendon tissue is inherently difficult for several reasons (i.e., slipping of the specimen from the clamp, stress concentrations, shortness of substance of ligaments). As a result, tensile tests have been performed with the ligament or tendon insertions to bone left anatomically intact (e.g., the entire bone-ligament-bone complex). From this test, a nonlinear (concave upwards) load-elongation curve for the bone-ligament-bone complex or muscle-tendon-bone complex can be obtained (Figure 1A). Parameters obtained from this curve, representing the structural properties of the complex, include stiffness, ultimate load, ultimate elongation, and energy absorbed at failure.

From the same uniaxial tensile test, a stress-strain curve of the ligament or tendon substance (from which its mechanical properties are determined) can also be obtained. This is done by normalizing the tensile load by the cross-sectional area (i.e., stress) and by normalizing the change in elongation in a defined region of the tissue midsubstance by the initial length (i.e., strain) (Figure $1 \mathrm{~B})$. One assumption in this test is that of a uniform stress distribution throughout the specimen. By engineering 

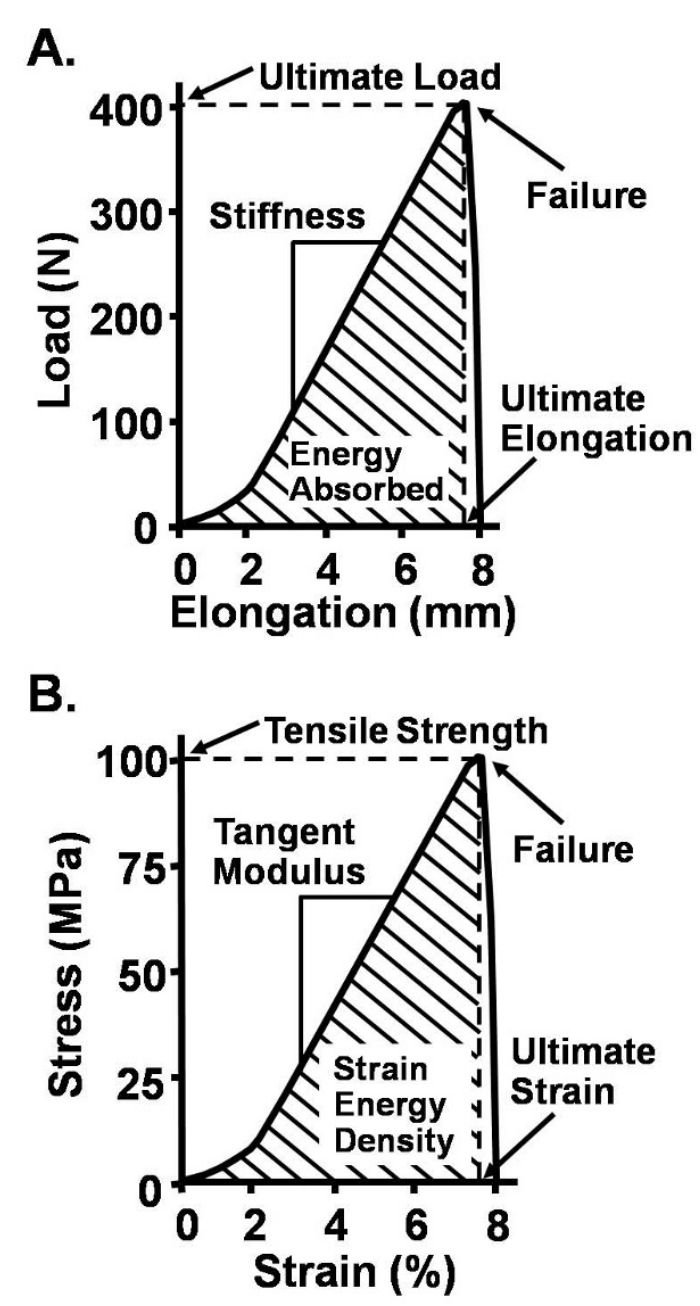

Figure I

A: A representative load-elongation curve of the bone-ligament-bone or muscle-tendon-bone complex. B: A stress-strain curve representing the mechanical properties of a ligament or tendon substance.

standards, this requires an aspect ratio (ratio of length to width) of greater than 10 to 1 . However, for biological tissues, a ratio of greater than 4 to 1 is generally accepted due to anatomical limitations. Parameters obtained from this curve, representing the mechanical properties, or quality, of the tissue substance include the tangent modulus, ultimate tensile stress (or tensile strength), ultimate strain, and strain energy density of the ligament or tendon substance.

\section{Methods to determine stress and strain}

As a specimen's cross-sectional area is required for stress calculations, methods to accurately measure it are important. However, the irregular, complex geometry presents challenges, and in some cases, can introduce very large errors. The literature has presented us with a long list of techniques [62-65]. In general, they can be divided into contact or noncontact approaches $[42,66]$. Contact methods include molding techniques, digital vernier calipers, and area micrometers [67]. We, as well as many others, have advocated the use of noncontact methods, so as not to disturb the natural shape of these soft tissues. These techniques include the shadow amplitude method [62], the profile method [64], and the use of a light source [63]. In our research center, laser micrometer systems have been developed to measure both the cross-sectional area and the shape of soft tissues with high accuracy and precision [42]. For those tissues that contain concavities, we have developed a more advanced laser reflectance system to accurately measure cross-sectional shape and area of these soft tissues [66].

Accurate experimental measurement of tissue strains also poses a number of hurdles. Methods, such as video tracking systems, have been developed to avoid possible errors of elongation from contribution of connecting structures [68-71]. Two or more reference markers are placed on the surface of the tendon or ligament substance, by means of Verhoeff's stain, elastin stain, or reflective tape, to serve as gauge lengths $[23,50]$. Then, a camera system could record the motion of the markers during tensile stretch, and the percentage strain of the tissue could be calculated [70]. Additionally, it must be noted that under tension, the strain along the ligaments and tendons can vary considerably. We have found that higher strains occur near the insertion sites [72]. To measure tissue elongation in-vivo, contact techniques such as the use of a differential variable reluctance transducer have been employed to obtain in-vivo strain of the ACL during physiologic motions [73].

The range of mechanical properties of various ligaments and tendons is very large as these tissues are designed specifically to function in different joints (Table 1) $[67,74$ 85]. For the human MCL, the tangent modulus and the tensile strength were found to be $332.2 \pm 58.3 \mathrm{MPa}$ and $38.6 \pm 4.8 \mathrm{MPa}$, respectively [74]. In comparison, values for the inferior glenohumeral ligament were found to be many folds lower than those for the MCL, ranging from 5 to $42 \mathrm{MPa}$ and 1 to $6 \mathrm{MPa}$, respectively [83]. The large range of motion and flexibility of the glenohumeral joint dictate such lower values.

Additionally, since ligaments and tendons are highly organized fibrous tissues, their mechanical properties are directionally dependent (anisotropic). For example, the human MCL has mechanical properties that are 30 times higher along its longitudinal direction compared to its transverse direction [74]. 
Table I: Mechanical properties of human ligaments and tendons

\begin{tabular}{|c|c|c|c|c|}
\hline Tissue & Modulus (MPa) & Ultimate Tensile Strength (MPa) & Ultimate Strain (\%) & Source \\
\hline \multicolumn{5}{|l|}{ Knee } \\
\hline Medial Collateral Ligament & $332 \pm 58$ & $39 \pm 5$ & $17 \pm 2$ & {$[74]$} \\
\hline Anterior Cruciate Ligament & $65-447$ & $13-46$ & $15-44$ & [75-77] \\
\hline Posterior Cruciate Ligament & $150-447$ & $30-36$ & $11-19$ & {$[67,75,78]$} \\
\hline Patellar Tendon & $504-680$ & $54-65$ & $12-15$ & {$[75,79,80]$} \\
\hline \multicolumn{5}{|l|}{ Lower extremity } \\
\hline Gracilis Tendon & $590-1734$ & $111-112$ & $7-19.4$ & {$[79,81]$} \\
\hline Semitendinosus Tendon & $540-1081$ & $89-124$ & $8-23$ & {$[79,81]$} \\
\hline Achilles Tendon & $819 \pm 208$ & $79 \pm 22$ & $9 \pm 2$ & {$[82]$} \\
\hline \multicolumn{5}{|l|}{ Shoulder } \\
\hline Inferior Glenohumeral Ligament & $5-42$ & $1-6$ & $8-33$ & {$[83,84]$} \\
\hline Posterior Glenohumeral Capsule & $10-32$ & $2-5$ & $22-23$ & [85] \\
\hline
\end{tabular}

\section{Determination of viscoelastic properties}

Ligaments and tendons display time- and history-dependent viscoelastic properties that reflect the complex interactions between proteins (e.g. type I, III, V collagen, elastin), ground substance (e.g. proteoglycans and glycolipids), and water. The loading and unloading curves of these tissues do not follow the same path but instead form a hysteresis loop representing internal energy dissipation during each cycle. Additional important viscoelastic characteristics of ligaments and tendons are creep (i.e., an increase in deformation over time under a constant load) and stress relaxation (i.e., a decline in stress over time under a constant deformation). These viscoelastic behaviors for ligaments and tendons have important clinical significance as they help to prevent fatigue failure of ligaments and tendons. For example, during walking or jogging, cyclic stress relaxation occurs, in which the peak stress in the tissue substance decreases with each cycle $[7,86]$.

Mathematical models have been made to describe the viscoelastic properties of ligaments and tendons. The quasilinear viscoelastic (QLV) theory originally formulated by Fung (1972) has been modified and adopted to describe the viscoelastic properties of the normal and healing MCL and ACL [87-96]. For ligaments and tendons undergoing larger deformations, a single integral finite strain (SIFS) theory has been implemented and used for the patellar tendon and ACL [97]. The interested readers are referred to others research articles and reviews for a more in-depth treatment of this subject area [88-90].

Factors influencing tensile properties of ligaments and tendons When tensile testing ligaments and tendons many factors can impact the outcome of their biomechanical properties. Those factors can be divided into 1) experimental factors, and 2) biological factors and can help the readers to identify why the findings on the same tissue can differ from study to study.
Specimen orientation during tensile testing, e.g. for the human femur-ACL-tibia complex (FATC), can alter its structural properties significantly because of its geometric complexity $[48,98]$. When tested in an anatomic orientation, by maintaining its natural insertion angles, the results became significantly differ from those tested in an orientation along the tibia [48]. For example, the ultimate load of specimens in the anatomic orientation was 35\% higher than those in the tibial orientation in young donors.

Considerable attention has also been given to the effects of the strain rate on the mechanical properties of ligaments and tendons [98-100]. Using skeletally mature rabbits, we could demonstrate little rate sensitivity over a range of four and a half decades of strain rates [98,101]. Other environmental conditions, including temperature and hydration, however, were found to have significant influence on the mechanical properties of ligaments and tendons [49,102]. Finally, appropriate storage by freezing with the muscles and joint intact were found to have little or no significant differences on its biomechanical properties after one or two freeze-thaw cycles. It should be cautioned that special care still must be taken in tissue sample storage, especially relating to protecting tissue before and after freezing from a lack of hydration $[50,103,104]$

Age-related changes are one biological factor worth discussing. Skeletal maturity has been shown to play a major role in the biomechanical properties of tendons and ligaments, because of the development at their insertions. For New Zealand white rabbits, the structural properties of the femur-MCL-tibia complex (FMTC) increased dramatically with skeletal maturity. For example, the stiffness in the skeletally mature group (12-15 months of age) were $40 \%$ higher than skeletally immature animals (4-6 months of age). Similar results were obtained for the mechanical properties of the ligament substance, as up to $90 \%$ increases in modulus were observed with skeletal maturity [51,105]. 
All skeletally immature FMTCs failed by tibial avulsion; whereas, the majority of skeletally mature animals failed at the tissue substance indicating that there is an asynchronous maturation process between the bone-ligamentbone complex and ligament midsubstance [51] (Figure 2). Prior to skeletal maturity, the strength of the MCL substance reached near its peak value, while the bone-ligament junction, especially at the proximal tibial insertion site, was still maturing, causing failure by tibial avulsion. Once skeletal maturity was reached, the proximal tibial insertion site became stronger, and the FMTC failed in the ligament substance.

The properties of ligaments and tendons also can change with advancing age as well as with activity level $[83,106,107]$. For example, in the human FATC, the mean stiffness and ultimate load of younger specimens (22-41 years) was 1.3 and 3.3 times higher, respectively, than those obtained from older specimens (60-97 years) [48].

Ligaments and tendons are also known to remodel according to applied motion and stress. Studies using rabbit hind limbs have shown that a few weeks of immobilization can severely increase joint stiffness as well as significantly decrease the structural properties of the FMTC and the mechanical properties of the MCL tissue

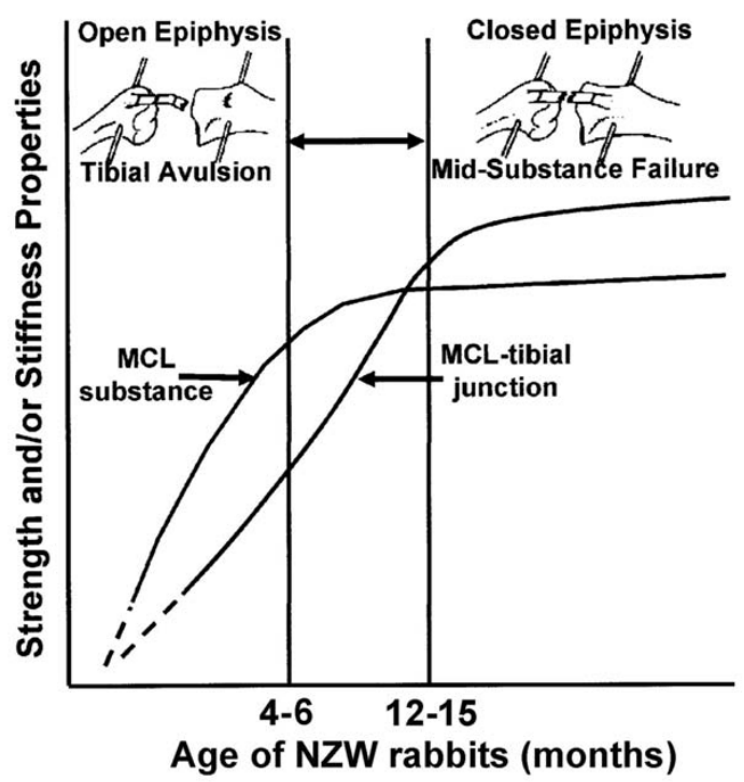

Figure 2

A schematic diagram depicting the relationship between failure mode and age, hypothesizing the asynchronous rates of maturation between the boneligament-bone complex and the ligament substance (permission requested from [5I]).
[47]. Remobilization could reverse these negative changes, but would require up to one year before these biomechanical properties could return to near normal levels [47]. On the other hand, exercise and training could only result in marginal increases in the biomechanical properties of ligaments (e.g. MCL of the knee) and tendons (e.g. extensor and flexor tendons of the hand) $[45,52,109]$. Based on these studies, a highly nonlinear curve could be drawn to represent the relationship between levels of stress and motion with the changes in properties for ligaments and tendons (Figure 3). Following immobilization, there would be a rapid reduction in tissue properties and mass from those for the normal range of physiological activities- as represented by the middle of the curve. In contrast, the positive gains following long-term exercise and training are much more moderate.

\section{Biomechanics and tendinopathy}

Tendinopathy, including tendinosis, tendonitis, and paratenonitis, is a work related and/or sports-induced ailment that involves severe discomfort and pain [9,110-115]. In general, tendons, after being subjected to repetitive loading of varying levels and for a prolonged period of time, could exhibit chronic pathology. Nevertheless, the etiology of tendinopathy is still unclear and hotly debated. Many years of research suggest that the problem is likely multifactorial [6,116-118]. Biomechanically, it is thought that microtrauma first occurs in the tendon, causing rupture of a small number of collagen fibrils while increasing the loading of the remainder [117-121]. The initial insult

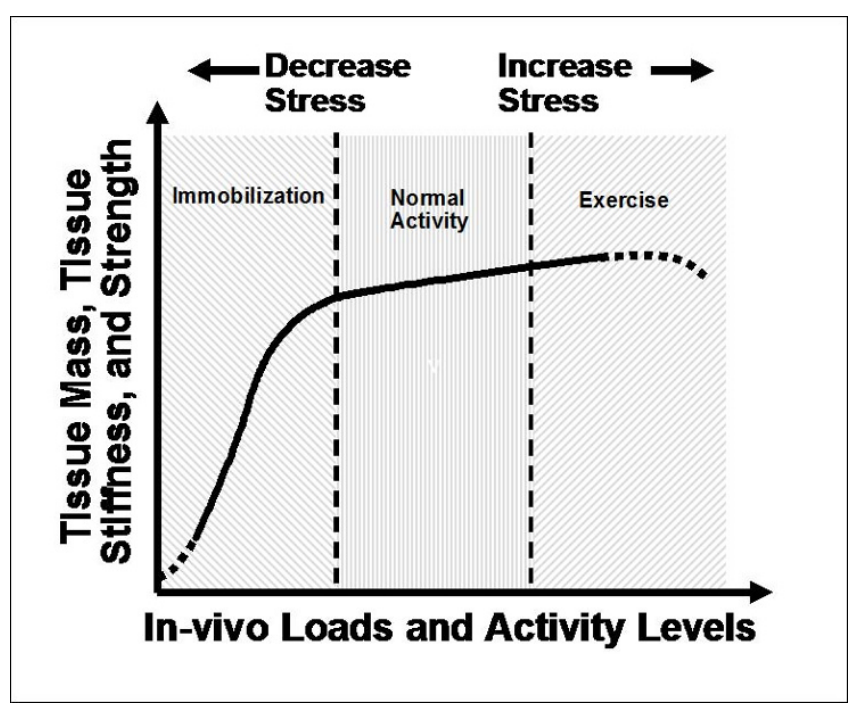

Figure 3

A schematic diagram describing the homeostatic responses of ligaments and tendons in response to different levels of stress and motion (permission requested from [47]). 


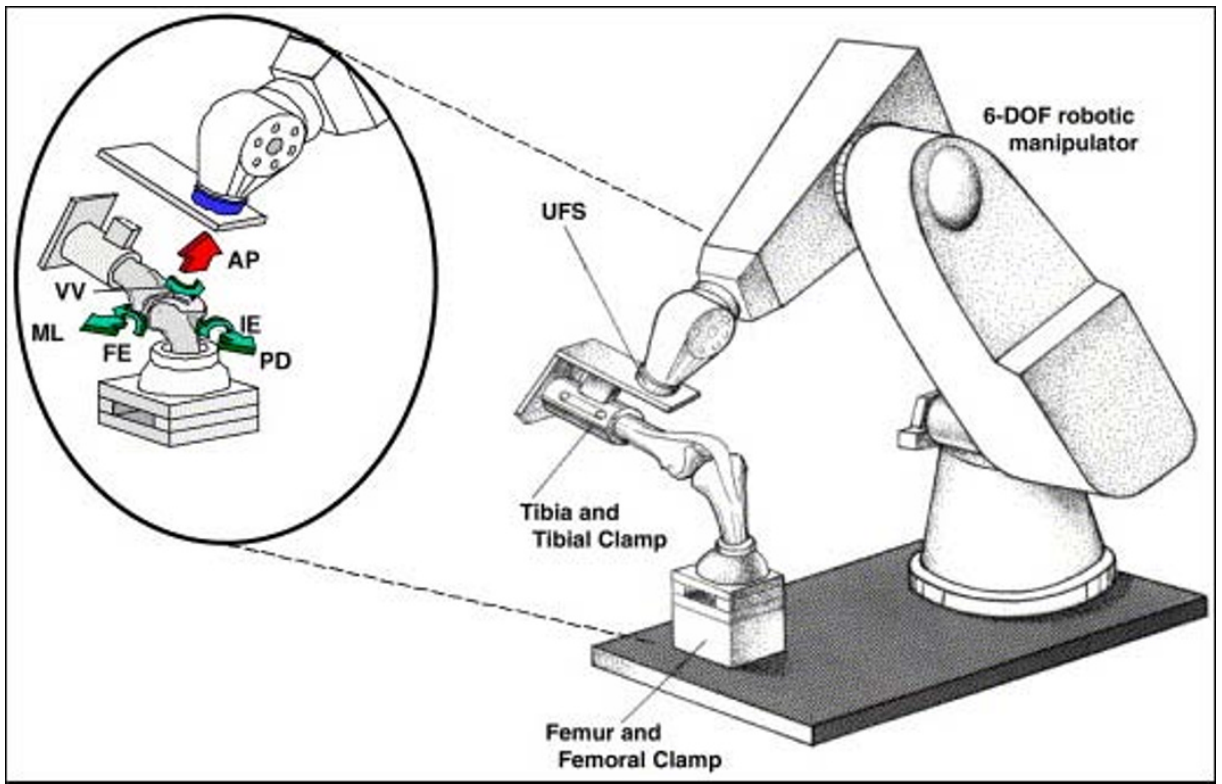

\section{Figure 4}

Schematic drawing illustrating a robotic/universal force-moment testing system and the six degrees of freedom of motion of the human knee joint (permission requested from [2/8]).

could be either due to one abnormal loading cycle of high (but subfailure) strain or a series of lower subfailure strains [70,110,122-129]. A number of in-vitro studies have shown that both loading regimens can induce such injury and the ensuing degeneration of tendons, is characterized by a reduction in their biomechanical properties [130-132].

A mechanism by which the trauma spreads to the remaining intact tendon until the symptoms of tendinopathy are presented has been suggested by a number of in-vitro experiments [110,116,119,128,133-136]. These studies have shown that high strains (or long duty cycles) applied by stretching bioreactors can cause tenocytes to produce abnormal levels of matrix metalloproteases (MMPs), which would in turn degrade the collagen and cause degeneration [131,137-144]. However, other studies have shown that loading protocols consisting of large strains were well-tolerated by tendon fibroblasts [6]. Whether these in-vitro strain levels simulate the physiological condition, and whether tensile loads that are within or slightly above the normal physiological range would cause any damage to the tendon fibroblasts are hotly debated [117]. Further, imaging studies of common sites of tendinopathy, e.g. for the supraspinatus tendon, patellar tendon, and Achilles tendon, were found to be in relatively lower levels of tensile strains than other parts of the tendon, suggesting that high tensile strains may not be the only major etiologic factor $[116,145,146]$.
Recently, in-vitro studies have demonstrated that understimulation of tenocytes can also lead to altered MMP expression and apoptosis, followed by tendon degeneration [147-152]. Others hypothesized that it is the compressive loading that leads to altered cellular morphology and degenerative changes [116,120,153-156]. Additionally, internal shear forces and heat have been postulated to be causes of intratendinous degeneration [6]. New finite element models of tendons may be useful tools to predict the response of these various loads on tendon cells and the resulting changes in extracellular matrix [157]. The literature has also shown other etiological factors, such as age, and gender, in the development of tendinopathy. Interested readers are referred to the International Olympic Committee Medal Commission publication Tendinopathy in Athletes edited by Woo, Renström, and Arnoczky for additional details [6]. Overall, it is clear that tendinopathies are complex biomechanical and biochemical problems.

\section{Management of tendinopathy}

Clinical management of tendinopathies are frequently empirically-based, and as such, the recommended treatment strategies by different clinicians can vary greatly. Although excessive exercise may be a cause of tendinopathy, eccentric exercise has been shown to work well in a number of studies to treat tendinopathy $[112,158,159]$. More than $80 \%$ of patients were satisfied with the treatment and were able to return to previous activity levels 


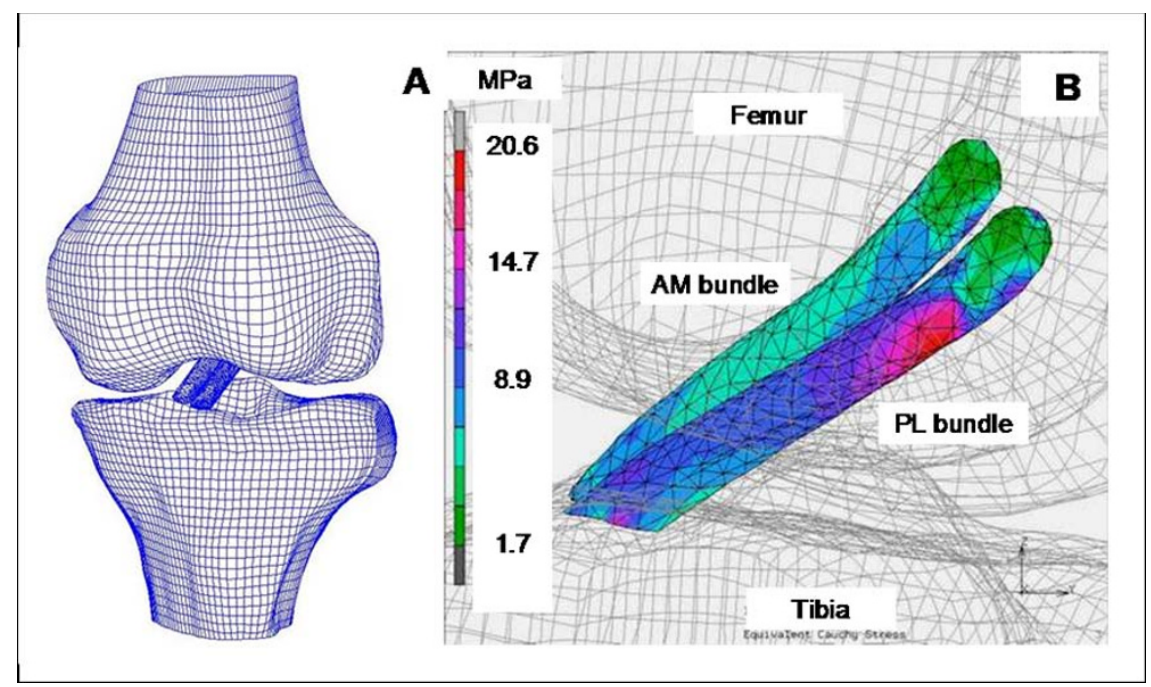

Figure 5

A) Finite element model of the knee joint and B) Cauchy stress distribution within the AM and PL bundles under a I $34 \mathrm{~N}$ anterior tibial load with the knee at full extension (lateral view). (permission requested from [228]).

[159-161]. Others have used traditional Chinese exercises, such as Tai Chi, to enhance body functions in promoting muscle performance, increasing flexibility and proprioception while weight bearing to stimulate bone and soft tissue [6]. These treatment strategies are supported by previous animal studies which have shown that moderate, prolonged exercise is effective and results in an increase in the cross-sectional area of swine extensor tendons as well as its mechanical properties, indicating improved tissue quality [109], as shown in Figure 3[162,163]. These changes contribute to the training-induced adaptation in mechanical properties, whereby exercise could improve tolerance toward strenuous exercise to avoid injury.

Additional modalities such as ultrasound, laser photostimulation, deep heat, pulsed magnetic and electromagnetic fields, and electrical stimulation are also used to treat tendinopathy [164-167]. Application of these modalities is intended to affect the stiffness of newly formed scar tissue inside the tendon. Yet other investigators use intratendinous injections of corticosteroids to relieve pain, but these injections may lead to negative effects on the mechanical properties [168-171].

When conservative treatment has failed, surgeons have used many techniques including needling, coblation, percutaneous tenotomy, arthroscopic debridement, percutaneous paratenon stripping, open tenotomy, paratenon stripping, and tendon grafting to treat tendinopathy [172]. In general, a return to sports after surgery has been reported in $60-85 \%$ of cases, although some have questioned these findings [173]. It has been suggested that first time ailments may require 2-3 months to recover but chronic cases may take 4-12 months [174]. As the physiologic, biomechanical, and biologic mechanisms of this ailment are not clearly understood, the general clinical advice remains that one must be patient as there is no "quick fix."

\section{Biomechanics and $A C L$ reconstruction}

For the ACL, it is well known that there is limited capacity for healing after its injury [36,175-177]. Unlike extraarticular ligaments, there exist several well known factors that limit the ACL from healing [178,179]. The thin synovium surrounding the ACL, which has been shown to play an important role in providing a vascular supply to the relatively avascular ACL as well as to protect it from the harsh synovial fluid [180], is disrupted and not regenerated until 1 to 2 months following ACL injury [175,181-183]. Histological examination of the human ACL reveals that it is also retracted following rupture and that clots formed are insufficient to fill the open gap [175]. In addition, a number of studies have also documented that the intrinsic healing capacities, cellular proliferation, and extracellular matrix (ECM) production of the ACL are also lower compared to the MCL $[24,178,179,181,184-188]$.

Most studies show unfavorable results after conservative treatment of an ACL rupture, particularly in patients with high levels of activity [189-193]. Overall success rate of conservative treatment for ACL has been about 30 to $50 \%$ $[37,189,194,195]$. Surgical replacements have been done for a large percentage of patients to help maintain knee stability [196-200]. Autografts, such as the bone-patellar 


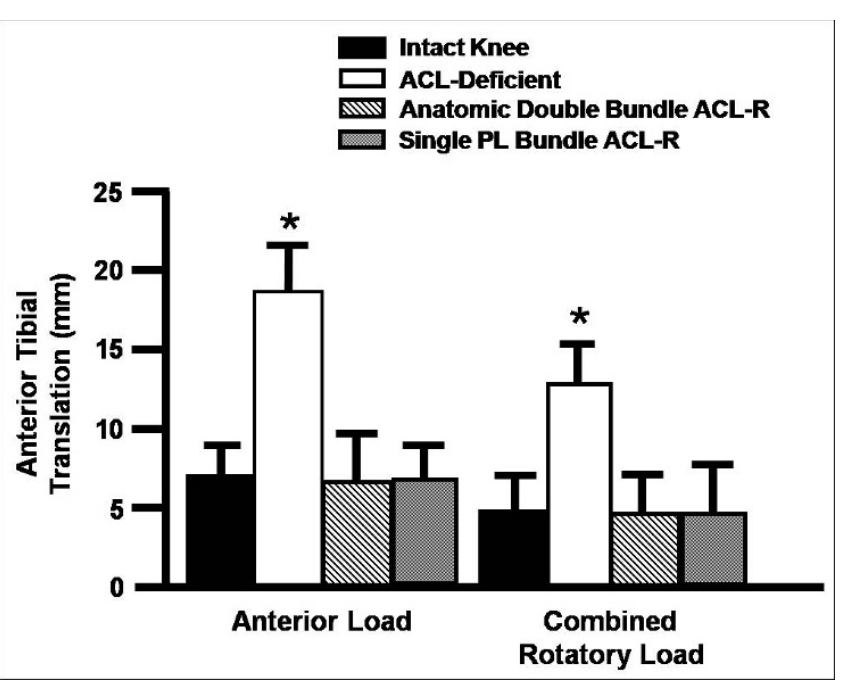

Figure 6

Anterior tibial translation (mean \pm SD) in the intact, anterior cruciate ligament (ACL)-deficient, and anatomic double bundle and single posterolateral (PL) bundle ACL-reconstructed (ACL-R) knees in response to an anterior tibial load and combined rotational load at $15^{\circ}$ of knee flexion. An asterisk indicates a statistically significant difference $(p<0.05)$ (permission requested from [232]).

tendon-bone (ВРТВ) and hamstring tendons, and allografts are the graft of choice. However, long-term followup studies (10+ years) of patients with ACL reconstruction showed 20-25\% unsatisfactory results, with complaints such as knee pain and extension deficits [78,201-204], and most concerning, many of these cases had progressed to knee osteoarthritis [205-217]. Much effort is being

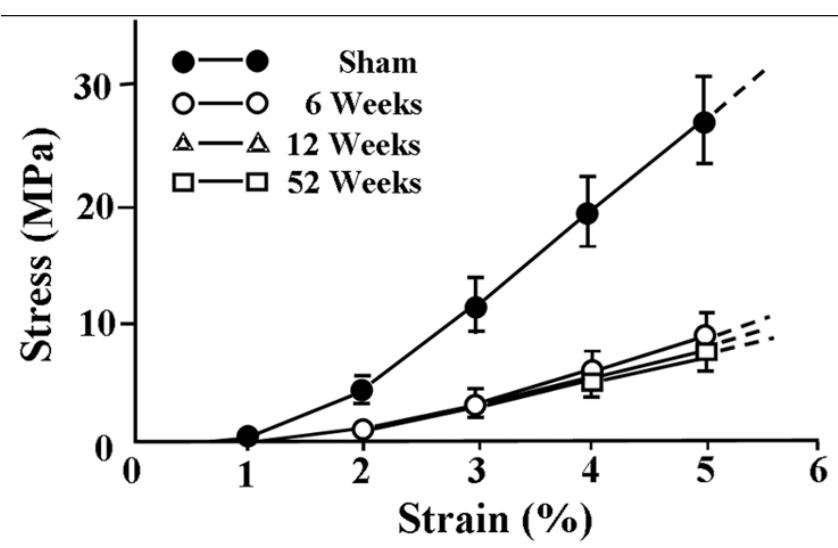

Figure 7

Stress-strain curves representing the mechanical properties of the medial collateral ligament substance for sham-operated and healing MCLs at time periods of $6(n=6), 12(n=6)$, and $52(n=4)$ weeks (permission requested from [22]). made to improve the clinical outcome. Biomechanical studies can be used to lead to better understanding of the kinematics of the knee and the function of the intact ACL and ACL replacement grafts in order to improve surgical decision making.

Complex anatomy of the $A C L$ and its role in knee function In the human knee, the ACL can be represented by two bundles: the anteromedial (AM) and the posterolateral (PL) bundle. The anatomic division of these bundles is based on the gross tensioning pattern of the ACL during passive flexion-extension of the knee, with the AM bundle tauter in flexion and the PL bundle tauter in extension. With these two bundles, the ACL is well designed to stabilize the knee throughout knee flexion under various loading conditions.

To assess the function of the ACL under multiple degree of freedom (DOF) knee motion, our research center has developed a robotic/universal force moment sensor (UFS) testing system since 1993 (Figure 4) [218]. This novel testing system can control and reproduce the multiple DOF knee motion [38,40,41,219-221] and is also capable of applying external loads to knees. By operating in both force and position control modes, the robot can apply a predetermined external load to the specimen, such as those used for the diagnosis of ACL deficiency [222-224], and the corresponding kinematics can be obtained. For example, an 134-N anterior tibial load can be applied to simulate the Lachman and anterior drawer tests, or a combined $10 \mathrm{~N} \cdot \mathrm{m}$ of valgus torque and $5 \mathrm{~N} \cdot \mathrm{m}$ of internal-external tibial torque can be applied to statically simulate the pivot-shift test. Then, the ACL can be transected. Subsequently, the specimen is moved along a previously recorded path of motion while the UFS records a new set of force and moment data [38]. Since the path of motion can be precisely repeated, the in-situ force in the ligament can be calculated by determining the changes in forces after cutting the ACL, based on the principle of superposition [41].

Most importantly, this advanced methodology has the advantage of collecting experimental data from the same cadaveric knee specimen under different experimental conditions (such as ACL intact, and ACL-reconstructed knee conditions), eliminating the effect of interspecimen variation. Thus, the robotic/UFS testing system has been used to quantitatively determine the data on motions of the intact, ligament deficient, and reconstructed knee with respect to the same reference position while the in-situ forces in ligaments and replacement grafts were calculated. As a result, the analysis of data through repeatedmeasures analysis of variance significantly increases the statistical power. To date, over 80 studies have been published using this technology, and it has been adopted by many laboratories around the world [225,226]. 


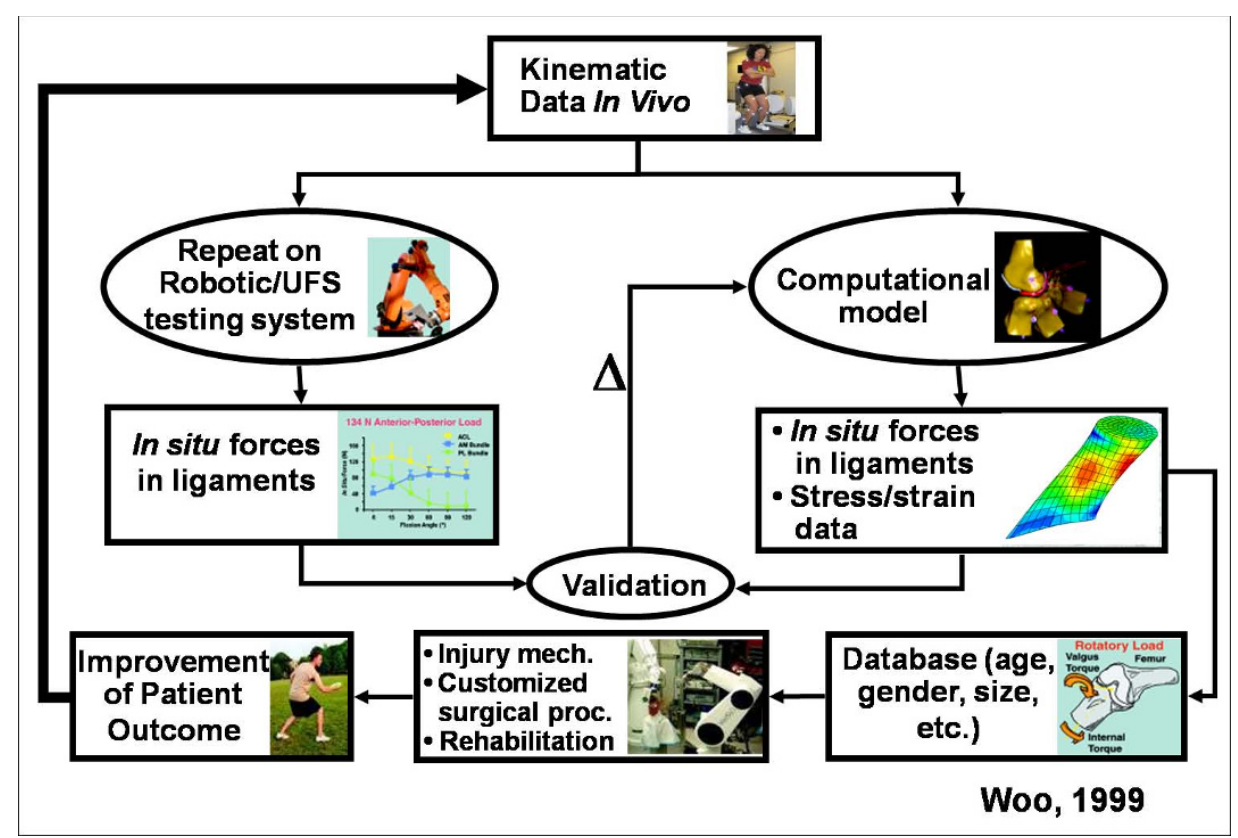

\section{Figure 8}

Flow chart showing the utilization of in-vivo kinematics data to drive experimental and computational methodologies leading to improved patient outcome (permission requested from [22I]).

We have found that the two anatomical bundles of the ACL have different functions even under the simplest external loading conditions [220]. For instance, it has been found that under an anterior tibial load, the PL bundle carried a higher load than the AM bundle with the knee near extension, and the AM bundle carried a higher load with the knee flexion angle larger than 30 degrees. It was also found that when the knee was subjected to combined rotatory loads of valgus and internal tibial torques to statically simulate the pivot shift test, the AM and PL bundles almost evenly shared the load at 15 degrees of knee flexion. Thus, the fact that both bundles play significant roles in controlling knee stability is well illustrated.

Computational finite element models are also valuable for studying for the complex function of the ACL and its bundles. Once such models are validated with experimental data (e.g., knee kinematics or in-situ forces as determined using the robotic/UFS testing system $[227,228]$ ), they can be used to calculate the stress and strain distribution in the ACL, by incorporating its non-uniform geometry (in which the midsubstance cross-sectional area is one-third that of the insertions) and its twisting fiber orientation. For example, it could be shown that the peak stresses in the ACL were seen near the femoral insertion sites, suggesting this area could be susceptible to injury (Figure 5). These results are consistent with clinical reports in which most ACL tears occur near the femoral insertion site [229].

\section{Choice of autograft}

As the majority of autografts for ACL reconstruction procedures are either bone-patellar tendon-bone or hamstrings tendon autografts, it is of interest to compare their biomechanical effectiveness to restore knee stability. To accomplish this goal, human cadaveric knees were tested using the robotic/UFS testing system following ACL reconstruction using a hamstrings tendon graft or bonepatellar tendon-bone graft [54]. Due to this unique system, both reconstructions were performed in the same knees and could be quantitatively compared. When an anterior tibial load was applied, both reconstructions were found to be successful in limiting excessive anterior tibial translation, and the in-situ forces in the grafts were near those of the intact ACL from full extension to $90^{\circ}$ of flexion. However, when a combined $10 \mathrm{~N}$-m valgus and 5 $\mathrm{N}$-m internal tibial torque was applied, both reconstructions were insufficient to reduce coupled anterior tibial translation. This insufficiency was further revealed by the significantly lower in-situ forces in the grafts, which ranged from $45 \%$ to $65 \%$ of that in the intact ACL. Thus, our data suggest better graft placement, i.e. the location of the femoral tunnel such that the graft could resist rotatory loads applied to knee, would be needed.

\section{Femoral tunnel location}

To investigate the effect of femoral tunnel location for ACL reconstruction grafts, a series of biomechanically based experiments have been performed in our research center 
$[54,55,230]$. First, we studied how well a bone-patellar tendon-bone autograft placed at the PL or AM insertion site in the femur (equivalent to the 10 and 11 o'clock positions in the frontal view) could restore knee function [231]. In response to an anterior tibial load, both the single PL-bundle and single AM-bundle reconstructions were able to restore anterior tibial translation to a level similar to that of the intact knee, except at deep knee flexion angles for the single PL-bundle reconstruction. Under combined rotatory loads, however, the single PL-bundle reconstruction could better restore the coupled anterior tibial translation and insitu force in the graft to those of the intact knee at $15^{\circ}$ and $30^{\circ}$ of knee flexion. Thus, although the grafts are similarly effective under an anterior tibial load, the more laterally placed single PL-bundle reconstruction could more effectively resist rotatory loads, particularly when the knee is near full extension.

We then considered a double bundle reconstruction by replacing both the AM and PL bundles so that it would better approximate the anatomy of the ACL, and compared it to a single AM bundle reconstruction. The double bundle reconstruction could not only better restore knee kinematics and in-situ force under anterior tibial loading but also under the combined rotatory loading. Additionally, the in-situ force at $30^{\circ}$ of flexion was $91 \% \pm 35 \%$ of the intact $\mathrm{ACL}$, compared to only $66 \% \pm 40 \%$ for the single AM bundle reconstruction under the rotatory loads.

A similar study was also done to compare the anatomic double bundle reconstruction to a more laterally placed single PL bundle reconstruction [232]. In this case, in response to anterior tibial and combined rotatory loads, both reconstructions were able to restore anterior tibial translation and in-situ force in the ACL graft near those for the intact knee at flexion angles less than $90^{\circ}$ of knee flexion. Moreover, there were no significant differences between the two reconstruction procedures at $15^{\circ}$ and $30^{\circ}$ of knee flexion under either loading condition (Figure $6, p<0.05)$. Thus, to reproduce the complex function of the ACL throughout the range of knee flexion, reproducing both bundles of the ACL may have some biomechanical advantages. On the other hand, a more laterally placed reconstruction, such as the single PL bundle reconstruction, may also work well, especially with the knee near extension where the function of the ACL is most critical.

\section{Biomechanics and ligament healing of the $M C L$}

Laboratory research has discovered that the injured MCL of the knee can heal spontaneously [24]. Conservative treatment of an isolated MCL injury has produced better or similar results to those with surgical repair either with or without immobilization, in terms of restoring varusvalgus knee stability and its biomechanical properties
[24,34]. Immobilization after ligament injury was shown to lead to a greater percentage of disorganized collagen fibrils, decreased structural properties of the FMTC, decreased mechanical properties of the ligament substance, and slower recovery of the resorbed insertion sites [47]. As a result, for the last twenty-five years the paradigm of clinical management of MCL tears has shifted from surgical repair with immobilization to functional management with early controlled motion $[186,233]$.

The MCL has been an excellent experimental model to help understand the rate, quality, and composition of healing ligaments and tendons as well as treatment modalities [24,234]. It has brought better understanding of the continuous process of healing. Roughly, it can be divided into three overlapping phases [24,72]. The inflammatory phase is marked by hematoma formation which starts immediately after injury and lasts for a few weeks. It is followed by the reparative phase where fibroblasts proliferate and produce a matrix of proteoglycan and collagen, especially type III collagen, to bridge between the torn ends. Over the next 6 weeks, an increasingly organized ECM formation, predominantly type I collagen, and cellular proliferation occur. Finally, the remodeling phase, which is marked by alignment of collagen fibers and increased collagen matrix maturation, can continue for years [72].

These changes are reflected in the structural properties of the healing FMTC which are inferior to controls at 12 weeks after injury [24]. However, by 52 weeks post-injury the stiffness of the injured FMTC recovered, but the ultimate load remained lower than those for the sham-operated MCL $[22,235,236]$. This return to normal is largely due to an increase in the cross-sectional area of the healing ligament to as much as $21 / 2$ times its normal size [237]. Thus, the recovery of the stiffness of the FMTC is largely the result of an increase in tissue quantity. On the other hand, the mechanical properties of the healing MCL midsubstance remain consistently inferior to those of the normal ligament and do not change with time up to one year $[24,237]$ (Figure 7). This means the healing process involves a larger quantity of lesser quality ligamentous tissue.

Clinical management of combined ligamentous injuries to the knee is obviously more difficult and remains controversial $[20,186,238,239]$. In the case of a combined ACL/MCL injury, our research center has utilized basic science studies to elucidate suitable treatments. As a first step, it is important to understand the contribution of each ligament to knee stability. For example, under a valgus torque, there was a $123 \%$ increase in valgus rotation of the knee after the ACL was transected in contrast to only a $21 \%$ increase when the MCL was transected, when the 
knee was allowed to move freely in 5 DOF (varus-valgus and internal-external tibial rotation, proximal-distal, anteroposterior, and medial-lateral translations) [240]. The MCL was only found to be the "primary" restraint to valgus rotation when the knee joint was artificially restrained to $3 \mathrm{DOF}$, i.e. axial tibial rotation and anteroposterior translation. As a result, after a MCL injury, the functional deficit in valgus rotation can be compensated for by the remaining structures, especially the ACL.

In a combined ACL/MCL injury model in the rabbit, it was demonstrated that MCL repair combined with ACL reconstruction restored valgus laxity and improved the structural properties of the FMTC over those with ACL reconstruction alone in the short term (12 weeks). However, at longer term (52 weeks), the advantages of the MCL repair on the biomechanical properties of the FMTC disappeared [30,237]. Therefore, it is apparent that only reconstruction of the ACL is necessary after a combined injury due to the important role the ACL plays in maintaining valgus instability.

Further studies of combined ACL/MCL injuries in the goat model using our robotic/UFS testing system have shown that the initially high in-situ force in the ACL graft was transferred to the healing MCL during the early stages of healing (i.e. from time zero to 6 weeks). These excessively high loads likely contributed to the observed decrease in the structural properties of the FMTC and tangent modulus of the MCL substance when compared to an isolated MCL injury $[23,241]$. Thus, future work is still needed to optimize treatment strategies following combined ligamentous injuries.

\section{Summary and future directions}

During the past four decades, significant advances have been made in characterizing the biomechanical properties of normal and injured ligaments and tendons. Data on the tensile and viscoelastic properties of ligaments and tendons, as well as knowledge on their contribution to joint kinematics and function, have significantly helped to move the field forward. Further, new findings on the healing process have led to improved treatment of ruptured ligaments and tendons, making it an exciting period for ligament and tendon research.

The new field of functional tissue engineering offers yet many new possibilities. The use of growth factors, gene therapy, cell therapy, and biological scaffolds to enhance healing certainly will result in improved outcomes [61,242-247]. We believe the ECM-derived bioscaffolds will play a significant role because it could accelerate the healing process and establish a bridge between the torn ends. ECM bioscaffolds have been successfully applied to improve MCL and PT healing, because their chemoattract- ant degradation products and bioactive agents allow aligned matrix formation with a concomitant improvement in biomechanical properties closer to normal values [58,248-250]. Efforts to healing of the ACL, which has long been considered as a "holy grail" for orthopaedics are now being made $[251,252]$. Additionally, it is possible to further improve the properties of these biological scaffolds by seeding bone marrow-derived cells (BMDCs) invitro followed by mechanical cyclic stretching to achieve better fiber alignment, thus making them to better suited to accelerate the healing process when used in-vivo [253].

While in-vitro testing has contributed significant advances, it is time to move on to in-vivo studies. To do this, we have developed a new higher payload robotic/ UFS testing system capable of handling levels of applied loads during activities of daily living (Figure 8). This system has also been shown to be highly accurate to $0.1 \mathrm{~mm}$ and $0.1^{\circ}$, which is needed to obtain meaningful data. Additionally, our collaborators at the Steadman-Hawkins Research Foundation have constructed a new biplanar fluoroscopy system, designed to measure in-vivo joint kinematics. It could measure the knee motion to within an accuracy of less than $0.2 \mathrm{~mm}$ and $0.3^{\circ}$ [253]. These accurate in-vivo kinematics data can then be reproduced on cadaveric knees utilizing the robotic/UFS testing system and the in-situ forces in the ACL can be obtained. Thus, the combined technology will allow us to identify mechanisms of ACL (as well as other ligament and tendon) injuries and to design and optimize reconstruction procedures and rehabilitation protocols leading to improved patient outcomes as well as to help athletes successfully return to sports.

Moreover, in-vivo kinematics can be used as inputs for a three-dimensional finite element model of the knee. The predicted results from the model must be first validated with experimental data such as those obtained from the robotics/UFS testing system. With a validated finite element model, it will be possible to calculate stress and strain distributions in the ACL and ACL grafts, as well as to develop a database of the in-situ forces for patients of different ages, genders, and sizes. These data are important for one to design preventative programs as well as surgical planning and rehabilitation protocols.

Nevertheless, ligament and tendon research will continue to present many challenges, including the prevention and treatment of tendinopathy as well as ligamentous injuries in addition to the reducing osteoarthritis following ACL injury. Solving these problems will require interdisciplinary and multidisciplinary collaborative research that involves biomedical engineers, biologists, clinicians, plus investigators from many other disciplines (i.e. mathematicians, statisticians and immunologists) to be working 
together to develop better therapeutic strategies. Ultimately, it is our hope to be able to make ligaments and tendons heal more completely with better tissue quality so that patients can return to both normal daily activities as well as sports.

\section{Competing interests}

The authors declare that they have no competing interests.

\section{Authors' contributions}

HJ, MF and SW all participated in drafting, editing, completion of the manuscript.

\section{Acknowledgements}

The authors acknowledge the financial support provided by the National Institute of Health (AR4I820 and AR39683) and National Science Foundation (Engineering Research Center, \#08I2348). We also wish to acknowledge the research contributions of past and present members of the Musculoskeletal Research Center as well as our collaborators, Dr. Michael Torry and Dr. Richard Steadman, of the Steadman-Hawkins Research Foundation.

\section{References}

I. Aglietti P, Buzzi R, Giron F, Simeone AJ, Zaccherotti G: Arthroscopic-assisted anterior cruciate ligament reconstruction with the central third patellar tendon. A 5-8-year follow-up. Knee Surg Sports Traumatol Arthrosc 1997, 5:138-144.

2. Bach BR Jr, Tradonsky S, Bojchuk J, Levy ME, Bush-Joseph CA, Khan $\mathrm{NH}$ : Arthroscopically assisted anterior cruciate ligament reconstruction using patellar tendon autograft. Five- to nineyear follow-up evaluation. Am J Sports Med 1998, 26:20-29.

3. Jomha NM, Borton DC, Clingeleffer AJ, Pinczewski LA: Long-term osteoarthritic changes in anterior cruciate ligament reconstructed knees. Clin Orthop Relat Res 1999:188-193.

4. Jomha NM, Pinczewski LA, Clingeleffer A, Otto DD: Arthroscopic reconstruction of the anterior cruciate ligament with patellar-tendon autograft and interference screw fixation. The results at seven years. J Bone Joint Surg Br 1999, 8 I:775-779.

5. Ritchie JR, Parker RD: Graft selection in anterior cruciate ligament revision surgery. Clin Orthop Relat Res 1996:65-77.

6. Woo SL-Y, Renstrom P, Arnoczky SP, Eds: Tendinopathy in Athletes. Blackwell Publishing; 2007.

7. Kannus P: Tendons-a source of major concern in competitive and recreational athletes. Scand J Med Sci Sports 1997, 7:53-54.

8. Renstrom P: Sports traumatology today. A review of common current sports injury problems. Ann Chir Gynaecol 1991, 80:81-93.

9. James SL, Bates BT, Osternig LR: Injuries to runners. Am J Sports Med 1978, 6:40-50.

10. Lysholm J, Wiklander J: Injuries in runners. Am J Sports Med I987, I5:168-171.

II. Teitz CC, Garrett WE Jr, Miniaci A, Lee MH, Mann RA: Tendon problems in athletic individuals. Instr Course Lect 1997, 46:569-582.

12. Miyasaka KC, Daniel DM, Stone ML, et al.: The incidence of knee ligament injuries in the general population. $A m J$ Knee Surg |991, 4:3-8.

13. Beaty J: Knee and leg: soft tissue trauma. In OKU orthopaedic knowledge update Ist edition. Edited by: Arendt EA. Rosemont, IL: American Academy of Orthopaedic Surgeons; 1999. xix, 442

14. Hovelius L: Incidence of shoulder dislocation in Sweden. Clin Orthop Relat Res 1982:127-131.

15. United States Census Bureau: United States Census 2000. 2000.

16. Sher JS, Uribe JW, Posada A, Murphy BJ, Zlatkin MB: Abnormal findings on magnetic resonance images of asymptomatic shoulders. J Bone Joint Surg Am 1995, 77:10-I5.

17. Lehman C, Cuomo F, Kummer FJ, Zuckerman JD: The incidence of full thickness rotator cuff tears in a large cadaveric population. Bull Hosp Jt Dis 1995, 54:30-31.
18. Frank C, Woo SL-Y, Amiel D, Harwood F, Gomez M, Akeson W: Medial collateral ligament healing. A multidisciplinary assessment in rabbits. Am J Sports Med 1983, I I:379-389.

19. Indelicato PA: Non-operative treatment of complete tears of the medial collateral ligament of the knee. J Bone Joint Surg Am 1983, 65:323-329.

20. Jokl P, Kaplan N, Stovell P, Keggi K: Non-operative treatment of severe injuries to the medial and anterior cruciate ligaments of the knee. J Bone Joint Surg Am 1984, 66:741-744.

2I. Kannus $P$ : Long-term results of conservatively treated medial collateral ligament injuries of the knee joint. Clin Orthop Relat Res 1988:103-II2.

22. Ohland KJ, Woo SL-Y, Weiss JA, Takai S, Shelley FJ: Healing of Combined Injuries of the Rabbit Medial Collateral Ligament and Its Insertions: A Long Term Study on the Effects of Conservative vs. Surgical Treatment. The Winter Annual Meeting of the American Society of Mechanical Engineers; Atlanta, GA I991:447-448.

23. Scheffler SU, Clineff TD, Papageorgiou CD, Debski RE, Benjamin C, Woo SL-Y: Structure and function of the healing medial collateral ligament in a goat model. Ann Biomed Eng 200I, 29:173-180.

24. Weiss JA, Woo SL-Y, Ohland KJ, Horibe S, Newton PO: Evaluation of a new injury model to study medial collateral ligament healing: primary repair versus nonoperative treatment. Journal of Orthopaedic Research 1991, 9:516-528.

25. Woo SL-Y, Gomez MA, Inoue M, Akeson WH: New experimental procedures to evaluate the biomechanical properties of healing canine medial collateral ligaments. J Orthop Res 1987, 5:425-432.

26. Hart RA, Woo SL-Y, Newton PO: Ultrastructural morphometry of anterior cruciate and medial collateral ligaments: an experimental study in rabbits. J Orthop Res 1992, 10:96-103.

27. Niyibizi C, Kavalkovich K, Yamaji T, Woo SL-Y: Type V collagen is increased during rabbit medial collateral ligament healing. Knee Surg Sports Traumatol Arthrosc 2000, 8:28I-285.

28. Abramowitch SD, Papageorgiou CD, Debski RE, Clineff TD, Woo SL$Y$ : A biomechanical and histological evaluation of the structure and function of the healing medial collateral ligament in a goat model. Knee Surg Sports Traumatol Arthrosc 2003, I I:I55-162.

29. Woo SL-Y, Niyibizi C, Matyas J, Kavalkovich K, Weaver-Green C, Fox RJ: Medial collateral knee ligament healing. Combined medial collateral and anterior cruciate ligament injuries studied in rabbits. Acta Orthopaedica Scandinavica 1997, 68: $142-148$

30. Yamaji T, Levine RE, Woo SL-Y, Niyibizi C, Kavalkovich KW, Weaver-Green CM: Medial collateral ligament healing one year after a concurrent medial collateral ligament and anterior cruciate ligament injury: an interdisciplinary study in rabbits. Journal of Orthopaedic Research 1996, I 4:223-227.

31. Buss DD, Min R, Skyhar M, Galinat B, Warren RF, Wickiewicz TL: Nonoperative treatment of acute anterior cruciate ligament injuries in a selected group of patients. Am J Sports Med 1995, 23: $160-165$

32. Ciccotti MG, Lombardo SJ, Nonweiler B, Pink M: Non-operative treatment of ruptures of the anterior cruciate ligament in middle-aged patients. Results after long-term follow-up. J Bone Joint Surg Am 1994, 76:1315-1321.

33. Maffulli N: Rehabilitation of an anterior cruciate ligament. Clin Orthop Relat Res 1997:253-255.

34. Fetto JF, Marshall JL: The natural history and diagnosis of anterior cruciate ligament insufficiency. Clin Orthop Relat Res 1980:29-38.

35. Hirshman HP, Daniel DM, Miyasaka K: The fate of the unoperated knee ligament injuries. In Knee ligaments: structure, function, injury, and repair Edited by: Daniel DM, Akeson WH, O'Connor JJ. New York: Raven Press; 1990:481-503.

36. Kannus $P$, Jarvinen $M$ : Conservatively treated tears of the anterior cruciate ligament. Long-term results. J Bone Joint Surg Am 1987, 69:1007-1012.

37. Noyes FR, Mooar PA, Matthews DS, Butler DL: The symptomatic anterior cruciate-deficient knee. Part I: the long-term functional disability in athletically active individuals. J Bone Joint Surg Am 1983, 65:154-162.

38. Fujie H, Livesay GA, Woo SL-Y, Kashiwaguchi S, Blomstrom G: The use of a universal force-moment sensor to determine in-situ 
forces in ligaments: a new methodology. J Biomech Eng 1995, I 1 7: I-7.

39. Lee TQ, Woo SL-Y: A new method for determining cross-sectional shape and area of soft tissues. J Biomech Eng 1988, I I0:II0-II4.

40. Livesay GA, Fujie H, Kashiwaguchi S, Morrow DA, Fu FH, Woo SL-Y: Determination of the in situ forces and force distribution within the human anterior cruciate ligament. Ann Biomed Eng 1995, 23:467-474.

41. Rudy TW, Livesay GA, Woo SL-Y, Fu FH: A combined roboticl universal force sensor approach to determine in situ forces of knee ligaments. J Biomech 1996, 29: I357-1360.

42. Woo SL-Y, Danto MI, Ohland KJ, Lee TQ, Newton PO: The use of a laser micrometer system to determine the cross-sectional shape and area of ligaments: a comparative study with two existing methods. J Biomech Eng 1990, I | 2:426-43 I.

43. Woo SL-Y, Gomez MA, Seguchi Y, Endo CM, Akeson WH: Measurement of mechanical properties of ligament substance from a bone-ligament-bone preparation. Journal of Orthopaedic Research 1983, I:22-29.

44. Gomez MA, Woo SL-Y, Amiel D, Harwood F, Kitabayashi L, Matyas JR: The effects of increased tension on healing medical collateral ligaments. Am J Sports Med 199I, 19:347-354.

45. Woo SL-Y, Gelberman RH, Cobb NG, Amiel D, Lothringer K, Akeson $\mathrm{WH}$ : The importance of controlled passive mobilization on flexor tendon healing. A biomechanical study. Acta Orthop Scand 198I, 52:615-622.

46. Woo SL-Y, Gomez MA, Akeson WH: The time and historydependent viscoelastic properties of the canine medical collateral ligament. J Biomech Eng 198I, 103:293-298.

47. Woo SL-Y, Gomez MA, Sites TJ, Newton PO, Orlando CA, Akeson $\mathrm{WH}$ : The biomechanical and morphological changes in the medial collateral ligament of the rabbit after immobilization and remobilization. J Bone Joint Surg Am 1987, 69: I200-12 II.

48. Woo SL-Y, Hollis JM, Adams DJ, Lyon RM, Takai S: Tensile properties of the human femur-anterior cruciate ligament-tibia complex. The effects of specimen age and orientation. $\mathrm{Am} \mathrm{J}$ Sports Med 1991, 19:217-225.

49. Woo SL-Y, Lee TQ, Gomez MA, Sato S, Field FP: Temperature dependent behavior of the canine medial collateral ligament. J Biomech Eng 1987, 109:68-71.

50. Woo SL-Y, Orlando CA, Camp JF, Akeson WH: Effects of postmortem storage by freezing on ligament tensile behavior. J Biomech 1986, 19:399-404.

5I. Woo SL-Y, Orlando CA, Gomez MA, Frank CB, Akeson WH: Tensile properties of the medial collateral ligament as a function of age. J Orthop Res 1986, 4:133-14I.

52. Woo SL-Y, Ritter MA, Amiel D, Sanders TM, Gomez MA, Kuei SC Garfin SR, Akeson WH: The biomechanical and biochemical properties of swine tendons-long term effects of exercise on the digital extensors. Connect Tissue Res 1980, 7:177-I83.

53. Debski RE, McMahon PJ, Thompson WO, Woo SL-Y, Warner JJ, Fu $\mathrm{FH}$ : A new dynamic testing apparatus to study glenohumeral joint motion. J Biomech 1995, 28:869-874.

54. Woo SL-Y, Kanamori A, Zeminski J, Yagi M, Papageorgiou C, Fu FH: The effectiveness of reconstruction of the anterior cruciate ligament with hamstrings and patellar tendon. A cadaveric study comparing anterior tibial and rotational loads. J Bone Joint Surg Am 2002, 84-A:907-9|4.

55. Yagi M, Wong EK, Kanamori A, Debski RE, Fu FH, Woo SL-Y: Biomechanical analysis of an anatomic anterior cruciate ligament reconstruction. Am J Sports Med 2002, 30:660-666.

56. Badylak SF, Tullius R, Kokini K, Shelbourne KD, Klootwyk T, Voytik SL, Kraine MR, Simmons C: The use of xenogeneic small intestinal submucosa as a biomaterial for Achilles tendon repair in a dog model. J Biomed Mater Res 1995, 29:977-985.

57. Hildebrand KA, Woo SL-Y, Smith DW, Allen CR, Deie M, Taylor BJ, Schmidt CC: The effects of platelet-derived growth factor-BB on healing of the rabbit medial collateral ligament. An in vivo study. Am J Sports Med 1998, 26:549-554.

58. Liang R, Woo SL-Y, Takakura Y, Moon DK, Jia F, Abramowitch SD: Long-term effects of porcine small intestine submucosa on the healing of medial collateral ligament: a functional tissue engineering study. J Orthop Res 2006, 24:8II-8I9.

59. Scherping SC Jr, Schmidt CC, Georgescu HI, Kwoh CK, Evans CH, Woo SL-Y: Effect of growth factors on the proliferation of lig- ament fibroblasts from skeletally mature rabbits. Connect Tissue Res 1997, 36: I-8.

60. Awad HA, Boivin GP, Dressler MR, Smith FN, Young RG, Butler DL: Repair of patellar tendon injuries using a cell-collagen composite. J Orthop Res 2003, $21: 420-431$.

6I. Murray MM, Spindler KP, Abreu E, Muller JA, Nedder A, Kelly M, Frino J, Zurakowski D, Valenza M, Snyder BD, Connolly SA: Collagen-platelet rich plasma hydrogel enhances primary repair of the porcine anterior cruciate ligament. J Orthop Res 2007, 25:8I-9I.

62. Ellis DG: Cross-sectional area measurements for tendon specimens: a comparison of several methods. J Biomech 1969 , 2:175-186.

63. laconis F, Steindler R, Marinozzi G: Measurements of cross-sectional area of collagen structures (knee ligaments) by means of an optical method. J Biomech 1987, 20:1003-1010.

64. Njus GO, Njus NM: A noncontact method for determining cross sectional area of soft tissues. Trans Orthop Res Soc 1968, II:I26.

65. Woo SL-Y, Akeson WH, Jemmott GF: Measurements of nonhomogeneous, directional mechanical properties of articular cartilage in tension. J Biomech 1976, 9:785-79|

66. Moon DK, Abramowitch SD, Woo SL-Y: The development and validation of a charge-coupled device laser reflectance system to measure the complex cross-sectional shape and area of soft tissues. J Biomech 2006, 39:307|-3075.

67. Race A, Amis AA: The mechanical properties of the two bundles of the human posterior cruciate ligament. J Biomech 1994 , 27:13-24.

68. Lam TC, Frank CB, Shrive NG: Calibration characteristics of a video dimension analyser (VDA) system. J Biomech 1992, 25: $|227-| 23 \mid$.

69. Smutz WP, Drexler M, Berglund LJ, Growney E, An KN: Accuracy of a video strain measurement system. J Biomech 1996, 29:8।3-8I7

70. Woo SL-Y: Mechanical properties of tendons and ligaments. I. Quasi-static and nonlinear viscoelastic properties. Biorheology 1982, 19:385-396.

7I. Yin FC, Tompkins WR, Peterson KL, Intaglietta M: A video-dimension analyzer. IEEE Trans Biomed Eng 1972, 19:376-38I.

72. Frank C, Woo SL-Y, Amiel D, Harwood F, Gomez M, Akeson W: Medial collateral ligament healing. A multidisciplinary assessment in rabbits. American Journal of Sports Medicine 1983, I I:379-389.

73. Beynnon BD, Fleming BC, Johnson RJ, Nichols CE, Renstrom PA Pope $\mathrm{MH}$ : Anterior cruciate ligament strain behavior during rehabilitation exercises in vivo. Am J Sports Med 1995, 23:24-34.

74. Quapp KM, Weiss JA: Material characterization of human medial collateral ligament. J Biomech Eng 1998, I 20:757-763.

75. Butler DL, Kay MD, Stouffer DC: Comparison of material properties in fascicle-bone units from human patellar tendon and knee ligaments. J Biomech 1986, 19:425-432.

76. Butler DL, Guan Y, Kay MD, Cummings JF, Feder SM, Levy MS: Location-dependent variations in the material properties of the anterior cruciate ligament. J Biomech 1992, 25:5 I I-5 I8.

77. Noyes FR, Grood ES: The strength of the anterior cruciate ligament in humans and Rhesus monkeys. J Bone Joint Surg Am 1976, 58:1074-1082.

78. Harner CD, Xerogeanes JW, Livesay GA, Carlin GJ, Smith BA, Kusayama T, Kashiwaguchi S, Woo SL-Y: The human posterior cruciate ligament complex: an interdisciplinary study. Ligament morphology and biomechanical evaluation. Am J Sports Med 1995, 23:736-745.

79. Butler DL, Grood ES, Noyes FR, Zernicke RF, Brackett K: Effects of structure and strain measurement technique on the material properties of young human tendons and fascia. J Biomech 1984, 17:579-596.

80. Johnson GA, Tramaglini DM, Levine RE, Ohno K, Choi NY, Woo SL$Y$ : Tensile and viscoelastic properties of human patellar tendon. J Orthop Res 1994, I 2:796-803.

8I. Kondo E, Yasuda K, Miyata K, Hara N, Kaneda K: Mechanical properties of the semitendinosus and gracilis tendons. Hokkaido Journal of Orthopaedics and Traumatology 1998, 40:13-15.

82. Wren TA, Yerby SA, Beaupre GS, Carter DR: Mechanical properties of the human achilles tendon. Clin Biomech (Bristol, Avon) 200I, I6:245-25I. 
83. Bigliani LU, Pollock RG, Soslowsky LJ, Flatow EL, Pawluk RJ, Mow VC: Tensile properties of the inferior glenohumeral ligament. J Orthop Res 1992, 10:187-197.

84. Moore SM, McMahon PJ, Debski RE: Bi-directional mechanical properties of the axillary pouch of the glenohumeral capsule: implications for modeling and surgical repair. J Biomech Eng 2004, I 26:284-288.

85. Moore SM, McMahon PJ, Azemi E, Debski RE: Bi-directional mechanical properties of the posterior region of the glenohumeral capsule. J Biomech 2005, 38:1365-1369.

86. Frank C, McDonald D, Shrive N: Collagen fibril diameters in the rabbit medial collateral ligament scar: a longer term assessment. Connective Tissue Research 1997, 36:26I-269.

87. Doehring TC, Carew EO, Vesely I: The effect of strain rate on the viscoelastic response of aortic valve tissue: a direct-fit approach. Ann Biomed Eng 2004, 32:223-232.

88. Abramowitch SD, Woo SL-Y: An improved method to analyze the stress relaxation of ligaments following a finite ramp time based on the quasi-linear viscoelastic theory. J Biomech Eng 2004, I 26:92-97.

89. Woo SL-Y, Abramowitch SD, Kilger R, Liang R: Biomechanics of knee ligaments: injury, healing, and repair. J Biomech 2006, 39:1-20.

90. Woo SL-Y, Johnson GA, Smith BA: Mathematical modeling of ligaments and tendons. J Biomech Eng 1993, I I 5:468-473.

91. Carew EO, Talman EA, Boughner DR, Vesely I: Quasi-Linear Viscoelastic theory applied to internal shearing of porcine aortic valve leaflets. J Biomech Eng 1999, I 2 1:386-392.

92. Kim SM, McCulloch TM, Rim K: Comparison of viscoelastic properties of the pharyngeal tissue: human and canine. Dysphagia 1999, 14:8-16.

93. Simon BR, Coats RS, Woo SL-Y: Relaxation and creep quasilinear viscoelastic models for normal articular cartilage. J Biomech Eng 1984, 106: 159-164.

94. Zheng YP, Mak AF: Extraction of quasi-linear viscoelastic parameters for lower limb soft tissues from manual indentation experiment. J Biomech Eng 1999, I 2 1:330-339.

95. Elliott DM, Robinson PS, Gimbel JA, Sarver JJ, Abboud JA, lozzo RV, Soslowsky LJ: Effect of altered matrix proteins on quasilinear viscoelastic properties in transgenic mouse tail tendons. Ann Biomed Eng 2003, 31:599-605.

96. Thomopoulos S, Williams GR, Gimbel JA, Favata M, Soslowsky LJ: Variation of biomechanical, structural, and compositional properties along the tendon to bone insertion site. J Orthop Res 2003, 21:413-419.

97. Johnson GA, Livesay GA, Woo SL-Y, Rajagopal KR: A single integral finite strain viscoelastic model of ligaments and tendons. J Biomech Eng 1996, I | 8:221-226.

98. Woo SL-Y, Peterson RH, Ohland KJ, Sites TJ, Danto MI: The effects of strain rate on the properties of the medial collateral ligament in skeletally immature and mature rabbits: a biomechanical and histological study. J Orthop Res 1990, 8:7|2-72I.

99. Noyes FR, DeLucas JL, Torvik PJ: Biomechanics of anterior cruciate ligament failure: an analysis of strain-rate sensitivity and mechanisms of failure in primates. J Bone Joint Surg Am 1974, 56:236-253.

100. Danto MI, Woo SL-Y: The mechanical properties of skeletally mature rabbit anterior cruciate ligament and patellar tendon over a range of strain rates. J Orthop Res 1993, II:58-67.

10I. Peterson RH, Woo SL-Y: A new methodology to determine the mechanical properties of ligaments at high strain rates. J Biomech Eng 1986, 108:365-367.

102. Haut RC, Powlison AC: The effects of test environment and cyclic stretching on the failure properties of human patellar tendons. J Orthop Res 1990, 8:532-540.

103. Moon DK, Woo SL-Y, Takakura Y, Gabriel MT, Abramowitch SD: The effects of refreezing on the viscoelastic and tensile properties of ligaments. J Biomech 2006, 39: I I53- I I 57.

104. Viidik A, Sanquist L, Magi M: Influence of postmortem storage on tensile strength characteristics and histology of rabbit ligaments. aCta Orthop Scand [Suppl] 1965, 79:1-38.

105. Woo SL-Y, Ohland KJ, Weiss JA: Aging and sex-related changes in the biomechanical properties of the rabbit medial collateral ligament. Mech Ageing Dev 1990, 56:129-142.

106. Rowe CR: Acute and recurrent anterior dislocations of the shoulder. Orthop Clin North Am 1980, I I:253-270.
107. Lee TQ, Dettling J, Sandusky MD, McMahon PJ: Age related biomechanical properties of the glenoid-anterior band of the inferior glenohumeral ligament-humerus complex. Clin Biomech (Bristol, Avon) 1999, I4:47|-476.

108. Woo SL-Y, Gomez MA, Woo YK, Akeson WH: Mechanical properties of tendons and ligaments. II. The relationships of immobilization and exercise on tissue remodeling. Biorheology 1982, 19:397-408.

109. Jozsa LG, Kannus P: Human Tendons: Anatomy, Physiology, and Pathology. Human Kinetics, Champaign, IL; 1997:164-253.

I I0. Maffulli N, Khan KM, Puddu G: Overuse tendon conditions: time to change a confusing terminology. Arthroscopy 1998, 14:840-843.

II I. Curwin S, Stanish WD: Tendinitis: Its Etiology and Treatment Lexington: Collamore Press; 1984.

I 12. Khan KM, Cook JL, Bonar F, Harcourt P, Astrom M: Histopathology of common tendinopathies. Update and implications for clinical management. Sports Med 1999, 27:393-408.

113. Clement DB, Taunton JE, Smart GW: Achilles tendinitis and peritendinitis: etiology and treatment. Am J Sports Med 1984, I 2:179-184.

I14. Karlsson J, Lundin O, Lossing IW, Peterson L: Partial rupture of the patellar ligament. Results after operative treatment. Am J Sports Med I99I, 19:403-408.

1 15. Maganaris CN, Narici MV, Almekinders LC, Maffulli N: Biomechanics and pathophysiology of overuse tendon injuries: ideas on insertional tendinopathy. Sports Med 2004, 34:1005-1017.

116. Arnoczky SP, Lavagnino M, Egerbacher M: The mechanobiological aetiopathogenesis of tendinopathy: is it the over-stimulation or the under-stimulation of tendon cells? Int J Exp Pathol 2007, 88:217-226

II7. Wang JH, losifidis MI, Fu FH: Biomechanical basis for tendinopathy. Clin Orthop Relat Res 2006, 443:320-332.

118. Archambault JM, Wiley JP, Bray RC: Exercise loading of tendons and the development of overuse injuries. A review of current literature. Sports Med 1995, 20:77-89.

119. Kannus P, Jozsa L: Histopathological changes preceding spontaneous rupture of a tendon. A controlled study of 89I patients. J Bone Joint Surg Am 1991, 73:1507-1525.

120. Khan KM, Cook JL, Kiss ZS, Visentini PJ, Fehrmann MW, Harcourt PR, Tress BW, Wark JD: Patellar tendon ultrasonography and jumper's knee in female basketball players: a longitudinal study. Clin J Sport Med 1997, 7:199-206.

12I. Fung DT, Wang VM, Laudier DM, Shine JH, Basta-Pljakic J, Jepsen KJ, Schaffler MB, Flatow EL: Subrupture tendon fatigue damage. J Orthop Res 2009, 27:264-273.

122. Soslowsky LJ, Carpenter JE, DeBano CM, Banerji I, Moalli MR: Development and use of an animal model for investigations on rotator cuff disease. J Shoulder Elbow Surg 1996, 5:383-392.

123. Soslowsky LJ, Thomopoulos S, Tun S, Flanagan CL, Keefer CC, Mastaw J, Carpenter JE: Neer Award 1999. Overuse activity injures the supraspinatus tendon in an animal model: a histologic and biomechanical study. J Shoulder Elbow Surg 2000, 9:79-84.

124. Viidik A: Simultaneous mechanical and light microscopic studies of collagen fibers. Z Anat Entwicklungsgesch 1972, 136:204-212.

125. Viidik A: Mechanical Properties of parallel-fibered collagenous tissues. In Biology of Collagen Edited by: Viidik A, Vuust J. London: Academic Press; 1980:237-255.

126. Kannus P: Etiology and pathophysiology of chronic tendon disorders in sports. Scand J Med Sci Sports 1997, 7:78-85.

127. Ker RF: The implications of the adaptable fatigue quality of tendons for their construction, repair and function. Comp Biochem Physiol A Mol Integr Physiol 2002, 1 33:987-1000.

128. Leadbetter WB: Cell-matrix response in tendon injury. Clin Sports Med 1992, 11:533-578.

129. Arnoczky SP, Lavagnino M, Whallon JH, Hoonjan A: In situ cell nucleus deformation in tendons under tensile load; a morphological analysis using confocal laser microscopy. J Orthop Res 2002, 20:29-35.

130. Almekinders LC, Banes AJ, Ballenger CA: Effects of repetitive motion on human fibroblasts. Med Sci Sports Exerc 1993, 25:603-607.

13I. van Griensven M, Zeichen J, Skutek M, Barkhausen T, Krettek C, Bosch U: Cyclic mechanical strain induces NO production in human patellar tendon fibroblasts-a possible role for remod- 
elling and pathological transformation. Exp Toxicol Pathol 2003, 54:335-338.

132. Potter HG, Hannafin JA, Morwessel RM, DiCarlo EF, O'Brien SJ, Altchek DW: Lateral epicondylitis: correlation of MR imaging, surgical, and histopathologic findings. Radiology 1995, 196:43-46.

133. Astrom M, Rausing A: Chronic Achilles tendinopathy. A survey of surgical and histopathologic findings. Clin Orthop Relat Res 1995:151-164.

134. Khan KM, Maffulli N, Coleman BD, Cook JL, Taunton JE: Patellar tendinopathy: some aspects of basic science and clinical management. $\mathrm{Br}$ / Sports Med 1998, 32:346-355.

135. Sharma $P$, Maffulli N: Tendon injury and tendinopathy: healing and repair. J Bone Joint Surg Am 2005, 87: 187-202.

136. Riley GP, Curry V, DeGroot J, van El B, Verzijl N, Hazleman BL, Bank RA: Matrix metalloproteinase activities and their relationship with collagen remodelling in tendon pathology. Matrix Biol 2002, 21: 185-195.

137. Banes AJ, Tsuzaki M, Hu P, Brigman B, Brown T, Almekinders L, Lawrence WT, Fischer T: PDGF-BB, IGF-I and mechanical load stimulate DNA synthesis in avian tendon fibroblasts in vitro. J Biomech 1995, 28:1505-1513.

138. Banes AJ, Horesovsky G, Larson C, Tsuzaki M, Judex S, Archambault J, Zernicke R, Herzog W, Kelley S, Miller L: Mechanical load stimulates expression of novel genes in vivo and in vitro in avian flexor tendon cells. Osteoarthritis Cartilage 1999, 7:14|-I53.

139. Skutek M, van Griensven M, Zeichen J, Brauer N, Bosch U: Cyclic mechanical stretching enhances secretion of Interleukin 6 in human tendon fibroblasts. Knee Surg Sports Traumatol Arthrosc 200I, 9:322-326.

140. Scott A, Khan KM, Heer J, Cook JL, Lian O, Duronio V: High strain mechanical loading rapidly induces tendon apoptosis: an ex vivo rat tibialis anterior model. Br J Sports Med 2005, 39:e25.

141. Archambault J, Tsuzaki M, Herzog W, Banes AJ: Stretch and interleukin-I beta induce matrix metalloproteinases in rabbit tendon cells in vitro. J Orthop Res 2002, 20:36-39.

142. Tsuzaki M, Bynum D, Almekinders L, Yang X, Faber J, Banes AJ: ATP modulates load-inducible IL-I beta, COX 2, and MMP-3 gene expression in human tendon cells. J Cell Biochem 2003, 89:556-562.

143. Wang JH, Jia F, Yang G, Yang S, Campbell BH, Stone D, Woo SL-Y: Cyclic mechanical stretching of human tendon fibroblasts increases the production of prostaglandin E2 and levels of cyclooxygenase expression: a novel in vitro model study. Connect Tissue Res 2003, 44:128-133.

144. Bey MJ, Ramsey ML, Soslowsky LJ: Intratendinous strain fields of the supraspinatus tendon: effect of a surgically created articular-surface rotator cuff tear. J Shoulder Elbow Surg 2002, I I:562-569.

145. Almekinders LC, Vellema JH, Weinhold PS: Strain patterns in the patellar tendon and the implications for patellar tendinopathy. Knee Surg Sports Traumatol Arthrosc 2002, 10:2-5.

146. Arnoczky SP, Tian T, Lavagnino M, Gardner K: Ex vivo static tensile loading inhibits MMP-I expression in rat tail tendon cells through a cytoskeletally based mechanotransduction mechanism. J Orthop Res 2004, 22:328-333.

147. Lavagnino M, Arnoczky SP: In vitro alterations in cytoskeletal tensional homeostasis control gene expression in tendon cells. J Orthop Res 2005, 23:12 II-I2I8.

148. Lavagnino M, Arnoczky SP, Egerbacher M, Gardner KL, Burns ME: Isolated fibrillar damage in tendons stimulates local collagenase mRNA expression and protein synthesis. J Biomech 2006, 39:2355-2362.

149. Lavagnino M, Arnoczky SP, Frank K, Tian T: Collagen fibril diameter distribution does not reflect changes in the mechanical properties of in vitro stress-deprived tendons. J Biomech 2005, 38:69-75.

150. Lavagnino M, Arnoczky SP, Tian T, Vaupel Z: Effect of amplitude and frequency of cyclic tensile strain on the inhibition of MMP-I mRNA expression in tendon cells: an in vitro study. Connect Tissue Res 2003, 44: 18I-I87.

151. Grinnell F, Zhu M, Carlson MA, Abrams JM: Release of mechanical tension triggers apoptosis of human fibroblasts in a model of regressing granulation tissue. Exp Cell Res 1999, 248:608-619.
152. Lyman J, Weinhold PS, Almekinders LC: Strain behavior of the distal achilles tendon: implications for insertional achilles tendinopathy. Am J Sports Med 2004, 32:457-46I.

153. Benjamin $M$, Ralphs JR: Fibrocartilage in tendons and ligaments-an adaptation to compressive load. J Anat 1998, 193(Pt 4):48I-494.

154. Jozsa L, Reffy A, Kannus P, Demel S, Elek E: Pathological alterations in human tendons. Arch Orthop Trauma Surg 1990, I I0:15-2I.

155. Vogel KG, Ordog A, Pogany G, Olah J: Proteoglycans in the compressed region of human tibialis posterior tendon and in ligaments. J Orthop Res 1993, I I:68-77.

156. Lavagnino M, Arnoczky SP, Kepich E, Caballero O, Haut RC: A finite element model predicts the mechanotransduction response of tendon cells to cyclic tensile loading. Biomech Model Mechanobiol 2008, 7:405-416.

157. Stanish WD, Rubinovich RM, Curwin S: Eccentric exercise in chronic tendinitis. Clin Orthop Relat Res 1986:65-68.

158. Alfredson H, Lorentzon R: Intratendinous glutamate levels and eccentric training in chronic Achilles tendinosis: a prospective study using microdialysis technique. Knee Surg Sports Traumatol Arthrosc 2003, I I:196-199.

159. Alfredson H, Pietila T, Jonsson P, Lorentzon R: Heavy-load eccentric calf muscle training for the treatment of chronic Achilles tendinosis. Am J Sports Med 1998, 26:360-366.

160. Mafi N, Lorentzon R, Alfredson H: Superior short-term results with eccentric calf muscle training compared to concentric training in a randomized prospective multicenter study on patients with chronic Achilles tendinosis. Knee Surg Sports Traumatol Arthrosc 200I, 9:42-47.

161. Magnusson SP, Kjaer M: Region-specific differences in Achilles tendon cross-sectional area in runners and non-runners. Eur J Appl Physiol 2003, 90:549-553.

162. Crameri RM, Langberg H, Teisner B, Magnusson P, Schroder HD, Olesen JL, Jensen CH, Koskinen S, Suetta C, Kjaer M: Enhanced procollagen processing in skeletal muscle after a single bout of eccentric loading in humans. Matrix Biol 2004, 23:259-264.

163. Windt DA van der, Heijden GJ van der, Berg SG van den, ter Riet G, de Winter AF, Bouter LM: Ultrasound therapy for musculoskeletal disorders: a systematic review. Pain 1999, 81:257-27I.

164. Rompe JD, Hopf C, Nafe B, Burger R: Low-energy extracorporeal shock wave therapy for painful heel: a prospective controlled single-blind study. Arch Orthop Trauma Surg 1996, I I 5:75-79.

165. Ohberg L, Alfredson H: Sclerosing therapy in chronic Achilles tendon insertional pain-results of a pilot study. Knee Surg Sports Traumatol Arthrosc 2003, I I:339-343.

166. Almekinders LC, Deol G: The effects of aging, antiinflammatory drugs, and ultrasound on the in vitro response of tendon tissue. Am J Sports Med 1999, 27:417-42I.

167. DaCruz DJ, Geeson M, Allen MJ, Phair I: Achilles paratendonitis: an evaluation of steroid injection. $\mathrm{Br} J$ Sports Med 1988, 22:64-65.

168. Price R, Sinclair H, Heinrich I, Gibson T: Local injection treatment of tennis elbow-hydrocortisone, triamcinolone and lignocaine compared. BrJ Rheumatol I991, 30:39-44.

169. Astrom $M$, Westlin N: No effect of piroxicam on achilles tendinopathy. A randomized study of $\mathbf{7 0}$ patients. Acta Orthop Scand 1992, 63:631-634.

170. Paavola M, Kannus P, Jarvinen TA, Jarvinen TL, Jozsa L, Jarvinen $M$ : Treatment of tendon disorders. Is there a role for corticosteroid injection? Foot Ankle Clin 2002, 7:50I-5I3.

17I. Maffulli N, Renstrom P, Leadbetter WB: Tendon Injuries: Basic Science and Clinical Medicine London: Springer; 2005.

172. Tallon C, Maffulli N, Ewen SW: Ruptured Achilles tendons are significantly more degenerated than tendinopathic tendons. Med Sci Sports Exerc 2001, 33:1983-1990.

173. Williams JG: Achilles tendon lesions in sport. Sports Med 1986, 3:114-135.

174. Murray MM, Martin SD, Martin TL, Spector M: Histological changes in the human anterior cruciate ligament after rupture. J Bone Joint Surg Am 2000, 82-A: I 387- I 397.

175. Wiig ME, Amiel D, VandeBerg J, Kitabayashi L, Harwood FL, Arfors KE: The early effect of high molecular weight hyaluronan (hyaluronic acid) on anterior cruciate ligament healing: an experimental study in rabbits. J Orthop Res 1990, 8:425-434. 
176. Andersson C, Odensten M, Good L, Gillquist J: Surgical or nonsurgical treatment of acute rupture of the anterior cruciate ligament. A randomized study with long-term follow-up. J Bone Joint Surg Am 1989, 71:965-974.

177. Nagineni CN, Amiel D, Green MH, Berchuck M, Akeson WH: Characterization of the intrinsic properties of the anterior cruciate and medial collateral ligament cells: an in vitro cell culture study. J Orthop Res 1992, 10:465-475.

178. Wiig ME, Amiel D, Ivarsson M, Nagineni CN, Wallace CD, Arfors KE: Type I procollagen gene expression in normal and early healing of the medial collateral and anterior cruciate ligaments in rabbits: an in situ hybridization study. J Orthop Res 199I, 9:374-382.

179. Arnoczky SP: Blood supply to the anterior cruciate ligament and supporting structures. Orthop Clin North Am 1985, 16:15-28.

180. Bray RC, Butterwick DJ, Doschak MR, Tyberg JV: Coloured microsphere assessment of blood flow to knee ligaments in adult rabbits: effects of injury. Journal of Orthopaedic Research 1996, 14:618-625.

18I. Bray RC, Rangayyan RM, Frank CB: Normal and healing ligament vascularity: a quantitative histological assessment in the adult rabbit medial collateral ligament. Journal of Anatomy 1996, I 88:87-95.

182. Murray MMaS KP: Anterior Cruciate Ligament Healing and Repair. Sports Med Arthrosc Rev 2005, 13:151-155.

183. Bray RC, Fisher AW, Frank CB: Fine vascular anatomy of adult rabbit knee ligaments. J Anat 1990, 172:69-79.

184. Frank C, Amiel D, Akeson WH: Healing of the medial collateral ligament of the knee. A morphological and biochemical assessment in rabbits. Acta Orthop Scand 1983, 54:917-923.

185. Indelicato $\mathrm{P}$ : Isolated medial collateral ligament injuries in the knee. J Am Acad Orthop Surg 1995, 3:9-14.

186. Lee J, Harwood FL, Akeson WH, Amiel D: Growth factor expression in healing rabbit medial collateral and anterior cruciate ligaments. lowa Orthop J 1998, 18:19-25.

187. Kobayashi K, Healey RM, Sah RL, Clark JJ, Tu BP, Goomer RS, Akeson $\mathrm{WH}$, Moriya $\mathrm{H}$, Amiel D: Novel method for the quantitative assessment of cell migration: a study on the motility of rabbit anterior cruciate (ACL) and medial collateral ligament (MCL) cells. Tissue Eng 2000, 6:29-38.

188. Barrack RL, Bruckner JD, Kneisl J, Inman WS, Alexander AH: The outcome of nonoperatively treated complete tears of the anterior cruciate ligament in active young adults. Clin Orthop Relat Res 1990:192-199.

189. Fink C, Hoser C, Benedetto KP, Hackl W, Gabl M: [Long-term outcome of conservative or surgical therapy of anterior cruciate ligament rupture]. Unfallchirurg 1996, 99:964-969.

190. Lobenhoffer $\mathrm{P}$, Tscherne $\mathrm{H}$ : [Rupture of the anterior cruciate ligament. Current status of treatment]. Unfallchirurg 1993, 96:150-168.

191. Scavenius M, Bak K, Hansen S, Norring K, Jensen KH, Jorgensen U: Isolated total ruptures of the anterior cruciate ligament-a clinical study with long-term follow-up of 7 years. Scand J Med Sci Sports 1999, 9:114-119.

192. Wittenberg RH, Oxfort HU, Plafki C: A comparison of conservative and delayed surgical treatment of anterior cruciate ligament ruptures. A matched pair analysis. Int Orthop 1998, 22: $145-148$.

193. Fink C, Hoser C, Benedetto KP: [Sports capacity after rupture of the anterior cruciate ligament-surgical versus non-surgical therapy]. Aktuelle Traumatol 1993, 23:37I-375.

194. Streich NA, Friedrich K, Gotterbarm T, Schmitt H: Reconstruction of the ACL with a semitendinosus tendon graft: a prospective randomized single blinded comparison of double-bundle versus single-bundle technique in male athletes. Knee Surg Sports Traumatol Arthrosc 2008, 16:232-238.

195. Aglietti P, Buzzi R, D'Andria S, Zaccherotti G: Arthroscopic anterior cruciate ligament reconstruction with patellar tendon. Arthroscopy 1992, 8:510-516.

196. Arnoczky SP, Tarvin GB, Marshall JL: Anterior cruciate ligament replacement using patellar tendon. An evaluation of graft revascularization in the dog. J Bone Joint Surg Am 1982, 64:217-224.

197. Cooper DE, Deng XH, Burstein AL, Warren RF: The strength of the central third patellar tendon graft. A biomechanical study. Am J Sports Med 1993, 21:818-823.
198. Jones KG: Reconstruction of the anterior cruciate ligament using the central one-third of the patellar ligament. J Bone Joint Surg Am 1970, 52:838-839.

199. Kurosaka M, Yoshiya S, Andrish JT: A biomechanical comparison of different surgical techniques of graft fixation in anterior cruciate ligament reconstruction. Am J Sports Med 1987, I5:225-229.

200. Salmon LJ, Russell VJ, Refshauge K, Kader D, Connolly C, Linklater J, Pinczewski LA: Long-term outcome of endoscopic anterior cruciate ligament reconstruction with patellar tendon autograft: minimum 13-year review. Am J Sports Med 2006, 34:721-732.

20I. Shelbourne KD, Nitz P: Accelerated rehabilitation after anterior cruciate ligament reconstruction. American Journal of Sports Medicine 1990, 18:292-299.

202. Aglietti P, Buzzi R, D'Andria S, Zaccherotti G: Patellofemoral problems after intraarticular anterior cruciate ligament reconstruction. Clin Orthop Relat Res 1993:195-204.

203. Jackson DW, Schaefer RK: Cyclops syndrome: Loss of extension following intra-articular anterior cruciate ligament reconstruction. Arthroscopy 1990, 6:171-178.

204. Maletius W, Messner K: Eighteen- to twenty-four-year followup after complete rupture of the anterior cruciate ligament. American Journal of Sports Medicine 1999, 27:71 I-7I7.

205. Salmon LJ, Russell VJ, Refshauge K, Kader D, Connolly C, Linklater J, Pinczewski LA: Long-term outcome of endoscopic anterior cruciate ligament reconstruction with patellar tendon autograft: Minimum 13-year review. American Journal of Sports Medicine 2006, 34:72I-732.

206. Roe J, Pinczewski LA, Russell VJ, Salmon LJ, Kawamata T, Chew M: A 7-year follow-up of patellar tendon and hamstring tendon grafts for arthroscopic anterior cruciate ligament reconstruction: Differences and similarities. American Journal of Sports Medicine 2005, 33:1337-1345.

207. Hertel P, Behrend H, Cierpinski T, Musahl V, Widjaja G: ACL reconstruction using bone-patellar tendon-bone press-fit fixation: 10-Year clinical results. Knee Surgery, Sports Traumatology, Arthroscopy 2005, 13:248-255.

208. Drogset JO, Grontvedt T, Robak OR, Molster A, Viset AT, Engebretsen L: A sixteen-year follow-up of three operative techniques for the treatment of acute ruptures of the anterior cruciate ligament. J Bone Joint Surg Am 2006, 88:944-952.

209. Jomha NM, Pinczewski LA, Clingeleffer A, Otto DD: Arthroscopic reconstruction of the anterior cruciate ligament with patellar-tendon autograft and interference screw fixation. The results at seven years. Journal of Bone and Joint Surgery - Series B 1999, 81:775-779.

210. Sommerlath K, Lysholm J, Gillquist J: The long-term course after treatment of acute anterior cruciate ligament ruptures. A 9 to 16 year followup. American Journal of Sports Medicine 1991, 19:156-162.

21I. Von Porat A, Roos EM, Roos H: High prevalence of osteoarthritis 14 years after an anterior cruciate ligament tear in male soccer players: a study of radiographic and patient relevant outcomes. Ann Rheum Dis. 2004 Mar;63(3):269-73 2004, 63(3):269-273.

212. Ait Si Selmi T, Fithian D, Neyret P: The evolution of osteoarthritis in 103 patients with ACL reconstruction at 17 years follow-up. Knee 2006, 13:353-358.

213. Fithian DC, Paxton EW, Stone ML, Luetzow WF, Csintalan RP, Phelan $D$, Daniel DM: Prospective trial of a treatment algorithm for the management of the anterior cruciate ligament-injured knee. American Journal of Sports Medicine 2005, 33:335-346.

214. Daniel DM, Stone ML, Dobson BE, Fithian DC, Rossman DJ, Kaufman KR: Fate of the ACL-injured patient. A prospective outcome study. American Journal of Sports Medicine 1994, 22:632-644.

215. Ruiz AL, Kelly M, Nutton RW: Arthroscopic ACL reconstruction: A 5-9 year follow-up. Knee 2002, 9:197-200.

216. Lohmander LS, Ostenberg A, Englund M, Roos H: High prevalence of knee osteoarthritis, pain, and functional limitations in female soccer players twelve years after anterior cruciate ligament injury. Arthritis Rheum 2004, 50:3|45-3।52.

217. Allen CR, Livesay GA, Wong EK, Woo SL-Y: Injury and reconstruction of the anterior cruciate ligament and knee osteoarthritis. Osteoarthritis Cartilage 1999, 7:110-121. 
218. Fujie H, Mabuchi K, Woo SL-Y, Livesay GA, Arai S, Tsukamoto Y: The use of robotics technology to study human joint kinematics: a new methodology. J Biomech Eng 1993, I I 5:2 I I-2 I 7.

219. Livesay GA, Rudy TW, Woo SL-Y, Runco TJ, Sakane M, Li G, Fu FH: Evaluation of the effect of joint constraints on the in situ force distribution in the anterior cruciate ligament. J Orthop Res 1997, I 5:278-284.

220. Woo SL-Y, Debski RE, Wong EK, Yagi M, Tarinelli D: Use of robotic technology for diathrodial joint research. J Sci Med Sport 1999, 2:283-297.

22I. Nielsen S, Helmig P: Instability of knees with ligament lesions. Cadaver studies of the anterior cruciate ligament. Acta Orthop Scand 1985, 56:426-429.

222. Sullivan D, Levy IM, Sheskier S, Torzilli PA, Warren RF: Medical restraints to anterior-posterior motion of the knee. J Bone Joint Surg Am 1984, 66:930-936.

223. Torzilli PA, Greenberg RL, Insall J: An in vivo biomechanical evaluation of anterior-posterior motion of the knee. Roentgenographic measurement technique, stress machine, and stable population. J Bone Joint Surg Am 198I, 63:960-968.

224. Fujie H, Sekito T, Orita A: A novel robotic system for joint biomechanical tests: application to the human knee joint. J Biomech Eng 2004, I 26:54-6I.

225. Gill TJ, DeFrate LE, Wang C, Carey CT, Zayontz S, Zarins B, Li G: The biomechanical effect of posterior cruciate ligament reconstruction on knee joint function. Kinematic response to simulated muscle loads. Am J Sports Med 2003, 3 I:530-536.

226. Li G, Gil J, Kanamori A, Woo SL-Y: A validated three-dimensional computational model of a human knee joint. J Biomech Eng 1999, I 2 I:657-662.

227. Song Y, Debski RE, Musahl V, Thomas M, Woo SL-Y: A threedimensional finite element model of the human anterior cruciate ligament: a computational analysis with experimental validation. J Biomech 2004, 37:383-390.

228. Sherman MF, Lieber L, Bonamo JR, Podesta L, Reiter I: The Iongterm followup of primary anterior cruciate ligament repair. Defining a rationale for augmentation. Am J Sports Med 1991, 19:243-255

229. Kanamori A, Woo SL-Y, Ma CB, Zeminski J, Rudy TW, Li G, Livesay $G A$ : The forces in the anterior cruciate ligament and knee kinematics during a simulated pivot shift test: A human cadaveric study using robotic technology. Arthroscopy 2000, 1 6:633-639.

230. Loh JC, Fukuda Y, Tsuda E, Steadman RJ, Fu FH, Woo SL-Y: Knee stability and graft function following anterior cruciate ligament reconstruction: Comparison between I I o'clock and 10 o'clock femoral tunnel placement. 2002 Richard O'Connor Award paper. Arthroscopy 2003, 19:297-304.

23I. Yamamoto Y, Hsu WH, Woo SL-Y, Van Scyoc AH, Takakura Y, Debski RE: Knee stability and graft function after anterior cruciate ligament reconstruction: a comparison of a lateral and an anatomical femoral tunnel placement. Am J Sports Med 2004, 32: 1825-1832.

232. Reider B, Sathy MR, Talkington J, Blyznak N, Kollias S: Treatment of isolated medial collateral ligament injuries in athletes with early functional rehabilitation. A five-year follow-up study. Am J Sports Med 1994, 22:470-477.

233. Woo SL-Y, Inoue M, McGurk-Burleson E, Gomez MA: Treatment of the medial collateral ligament injury. II: Structure and function of canine knees in response to differing treatment regimens. American Journal of Sports Medicine 1987, I 5:22-29.

234. Inoue M, Woo SL-Y, Gomez MA, Amiel D, Ohland KJ, Kitabayashi LR: Effects of surgical treatment and immobilization on the healing of the medial collateral ligament: a long-term multidisciplinary study. Connect Tissue Res 1990, 25:13-26.

235. Loitz-Ramage BJ, Frank CB, Shrive NG: Injury size affects longterm strength of the rabbit medial collateral ligament. Clinical Orthopaedics \& Related Research 1997:272-280.

236. Ohno K, Pomaybo AS, Schmidt CC, Levine RE, Ohland KJ, Woo SL$Y$ : Healing of the medial collateral ligament after a combined medial collateral and anterior cruciate ligament injury and reconstruction of the anterior cruciate ligament: comparison of repair and nonrepair of medial collateral ligament tears in rabbits. J Orthop Res 1995, 13:442-449.

237. Frolke JP, Oskam J, Vierhout PA: Primary reconstruction of the medial collateral ligament in combined injury of the medial collateral and anterior cruciate ligaments. Short-term results. Knee Surg Sports Traumatol Arthrosc 1998, 6:103-106.

238. Hillard-Sembell D, Daniel DM, Stone ML, Dobson BE, Fithian DC: Combined injuries of the anterior cruciate and medial collateral ligaments of the knee. Effect of treatment on stability and function of the joint. J Bone Joint Surg Am 1996, 78: I69-I76.

239. Inoue M, McGurk-Burleson E, Hollis JM, Woo SL-Y: Treatment of the medial collateral ligament injury. I: The importance of anterior cruciate ligament on the varus-valgus knee laxity. Am J Sports Med 1987, I 5:15-21.

240. Abramowitch SD, Yagi M, Tsuda E, Woo SL-Y: The healing medial collateral ligament following a combined anterior cruciate and medial collateral ligament injury-a biomechanical study in a goat model. J Orthop Res 2003, 2 I: I I 24- I I 30.

24I. Bellincampi LD, Closkey RF, Prasad R, Zawadsky JP, Dunn MG: Viability of fibroblast-seeded ligament analogs after autogenous implantation. J Orthop Res 1998, I 6:4|4-420.

242. Spindler KP, Murray MM, Detwiler KB, Tarter JT, Dawson JM, Nanney $L B$, Davidson JM: The biomechanical response to doses of TGF-beta 2 in the healing rabbit medial collateral ligament. J Orthop Res 2003, 2 I:245-249.

243. Woo SL-Y, Takakura Y, Liang R: Treatment with bioscaffold enhances the collagen composition and fibril morphology of the healing medial collateral ligament in rabbits. Tissue Eng 2006, I2:159-166.

244. Liang R, Woo SL-Y, Takakura Y, Moon DK, Jia F, Abramowitch SD: Long-term effects of porcine small intestine submucosa on the healing of medial collateral ligament: a functional tissue engineering study. J Orthop Res 2006, 24:8I I-8I9.

245. Jacobson M, Fufa D, Abreu EL, Kevy S, Murray MM: Platelets, but not erythrocytes, significantly affect cytokine release and scaffold contraction in a provisional scaffold model. Wound Repair Regen 2008, 1 6:370-378.

246. Agung M, Ochi M, Yanada S, Adachi N, Izuta Y, Yamasaki T, Toda K: Mobilization of bone marrow-derived mesenchymal stem cells into the injured tissues after intraarticular injection and their contribution to tissue regeneration. Knee Surg Sports Traumatol Arthrosc 2006, I4:|307-I3|4.

247. Karaoglu S, Fisher MB, Woo SL-Y, Fu YC, Liang R, Abramowitch SD: Use of a Bioscaffold to Improve Healing of a Patellar Tendon Defect After Graft Harvest for ACL Reconstruction: A Study in Rabbits. J Orthop Res 2008, 26:255-263.

248. Woo SL-Y, Takakura Y, Liang R, Jia F, Moon DK: Treatment with bioscaffold enhances the the fibril morphology and the collagen composition of healing medial collateral ligament in rabbits. Tissue Eng 2006, I2:159-166.

249. Liang R, Woo SL-Y, Nguyen TD, Liu PC, Almarza A: Effects of a bioscaffold on collagen fibrillogenesis in healing medial collateral ligament in rabbits. J Orthop Res 2008, 26: I 098-I 104.

250. Murray MM: Current status and potential of primary ACL repair. Clin Sports Med 2009, 28:5I-6I.

25I. Murray MM, Fleming BC, Abreu E, Magarian E, Mastrangelo A, Palmer M, Spindler KP: Collagen-Platelet Rich Plasma Hydrogel Enhances Primary Repair of the Porcine Anterior Cruciate Ligament. International Symposium on Ligaments and Tendons VIII; March I: Stanford, CA 2008:38.

252. Nguyen TD, Liang R, Woo SL-Y, Burton SD, Wu C, Almarza A, Sacks MS, Abramowitch S: Effects of Cell Seeding and Cyclic Stretch on the Fiber Remodeling in an Extracellular Matrix-Derived Bioscaffold. Tissue Eng Part A 2009, I 5:957-963.

253. Giphart JE, Shelburne KB, Anstett K, Brunkhorst JP, Pault JD, Woo SL-Y, Steadman JR, Torry MR: Measurement of 3D In Vivo Knee Motion Using Biplane Fluoroscopy: Investigation of Noncontact ACL Injuries. XVIth International Conference on Mechanics in Medicine and Biology; July 23-25; Pittsburgh, PA 2008. 